\title{
Financial implications of relationship breakdown: does marriage matter?*
}

\author{
Hayley Fisher \\ University of Sydney \\ Hamish Low
University of Cambridge and IFS
}

March 24, 2015

\begin{abstract}
In raw data in the UK, the income loss on separation for women who were cohabiting is less than the loss for those who were married. Cohabitants lose less even after controlling for observable characteristics including age and the number of children. This difference is not explained by differences in access to benefits or labor supply responses after separation. In contrast, there is no difference in the change in household income experienced by cohabiting and married men who do better on average than both groups of women. We show that the difference for women arises because of differences in the use of family support networks: cohabitants' standard of living falls by less because they are more likely to live with other adults, particularly their family, following separation, even after controlling for age and children. Divorced women do not return to living with their extended families. The greater legal protection offered by marriage does not appear to translate into economic protection.
\end{abstract}

Keywords: divorce, cohabitation, income loss

JEL Classification: D10, J12

${ }^{*}$ Low thanks funding from the ESRC as a Research Fellow, grant number RES-063-27-0211. We are especially grateful to Tom Crossley, Pramila Krishnan and Jo Miles for helpful comments. Addresses: Hayley Fisher, School of Economics, University of Sydney, NSW 2006, Australia, Email: hayley.fisher@sydney.edu.au; Hamish Low (correspondence), Faculty of Economics, Sidgwick Avenue, Cambridge CB3 9DD, UK, Tel: +44 1223 335221, Email: hamish.low@econ.cam.ac.uk 


\section{Introduction}

When relationships end, there are often significant financial consequences for both partners. Both lose the economies of scale of partnership, but there may be differences between men and women in the extent of hardship that separation imposes, and differences that arise from whether the relationship was one of marriage or cohabitation 11 This paper addresses the importance of these differences, and focuses in particular on the question of whether married women are subject to different outcomes than cohabiting women when a relationship ends.

Unmarried cohabitation is widespread in the UK and is increasingly viewed as an acceptable alternative to legal marriage (Haskey 2001). The rise of unilateral and no-fault divorce makes the difference between separating from marriage and cohabitation less stark than when divorce required both parties to consent. However, there are still substantial differences in the allocation of assets and income after separation (see Fisher, 2012, and Voena, 2010). For divorcing couples, there have been moves in the UK towards greater equity in sharing assets and towards recognizing the contributions often made by women within marriage to the future earnings of their husbands (see Miles and Probert, 2009), and these moves lessen the cost of divorce for women. On the other hand, in England and Wales, no such protection exists for cohabitants who separate 2 This legal protection of married women suggests that, if otherwise identical to the cohabitants, married women should suffer smaller income falls on separation. Perhaps surprisingly then, we show using UK data from the British Household Panel Survey (BHPS) that, in the raw data, income losses for women separating from cohabitation are significantly less than for women divorcing. Similar results have been found in the US (Avellar and Smock 2005) and the Netherlands (Manting and Bouman 2006) $!^{3}$ The contribution of this paper is to understand how much of this apparent better outcome for cohabitants can be explained by differences in characteristics within the relationship, such as the presence of children, and how much by differences in behavior and available mechanisms for recovery after breakdown.

We find that, after controlling for individual characteristics at the time of separation, the fall in household income adjusted for household composition ('equivalized income'), on separation for married women is $51 \%$, whereas for cohabiting women it is $31 \%$. Our focus in this paper is understanding this difference. By contrast, for men, equivalized household income increases by around $20 \%$ on relationship breakdown, with no statistically significant difference by marital status.

\footnotetext{
${ }^{1}$ We use the term "cohabitation" to refer to a cohabiting relationship where the individuals act as if married but are not in fact married. We use the term "separation" to refer to the ending of either type of relationship, then specifically "divorce" to refer to the end of a marriage.

${ }^{2}$ In Scotland, the law changed in 2009 to allow some protection for cohabitants under family law. It is not clear yet whether this has changed substantially the cost of separating from cohabitation. Other countries, such as Canada and Australia, confer similar protections on cohabitants after a given length of time.

${ }^{3}$ There is also substantial evidence that the income losses experienced by women after separating are larger than those experienced by men (see Duncan and Hoffman 1985, Bianchi, Subaiya and Kahn 1999, McManus and DiPrete 2001, McKeever and Wolfinger 2002, Gray and Chapman 2007, Gadalla 2009, Uunk 2004, Aassve et al 2007, Jenkins (2009), Fisher and Low (2009)). Most of these studies do not distinguish between marriage and cohabitation.
} 
The difference between cohabiting women and married women in the raw data is difficult to interpret because of the problem of selection. In particular, whether a couple are married or cohabiting is not random, and whether a relationship ends or not is not random and is unlikely to be independent of marital status: characteristics that affect the probability of being married rather than cohabiting, such as the presence of children, also affect the cost of relationship breakdown. Further, behavior after a relationship ends may differ because of different private and social support mechanisms. For example, Fisher and Low (2009) show that repartnering is harder in the presence of children and when older, and that repartnering is an important mechanism for regaining economies of scale and maintaining equivalized income. The point about selection is that if married couples have fewer ways to mitigate loss on separation and have access to poorer support mechanisms, they may only actually separate when the marriage is especially bad, in which case those who are observed to separate are those who are willing to accept large falls in household income in order to end the marriage. On the other hand, the higher financial and emotional costs of divorce relative to separation are unlikely to be captured by changes in observed household income, and so married couples may have smaller falls in observed household income than otherwise similar cohabiting couples, with the additional costs remaining uncaptured by measured household income. We provide a framework for understanding these various selection and behavioral issues.

Controlling for observable characteristics at the time of relationship breakdown, the fall in equivalized income is about $30 \%$ greater for divorcees than cohabitants for women without a child under 3, but the difference becomes insignificant for women with infants. The remaining difference for those without infants can be explained by differences in support mechanisms and behavior after separation: the main difference is in greater support for cohabitants from other family members and in the consequent living arrangements, rather than differences in labor supply behavior or government support. Cohabitants are more likely to live with other adults, particularly other family members, after separation and this provides financial support. Postseparation, $19 \%$ of cohabitants return to living with their extended families, whereas only $4 \%$ of divorcees return. We show that this is not driven by divorcees having greater access to the former home and so not needing the support. This difference in outcomes is no longer present if we assume that there is no income sharing in the new household and so other adults do not provide any transfers.

These results suggest a difference in the support mechanisms used by married and cohabiting women: once a woman is married, she is significantly less likely to return to her family in the event of relationship breakdown, and more likely to repartner, even after controlling for age and children. Marriage is associated with different social support networks. Whilst this might reflect the selection issues mentioned above, this result may also reflect the difference in the social standing of marriage and cohabitation. The status of being married or divorced might change the perception of need for support, and so damage the social support 
networks available to a woman.

On the other hand, we find no evidence that cohabitants are disadvantaged in terms of income loss by having less protection by the law. The main caveat is that we have only limited information on income transfers between former partners 4 and we would expect these transfers to differ between those who were previously married and previously cohabiting.

Section 2 provides a framework for thinking about the cost of separation from marriage and cohabitation. Section 3 describes our data source and sample. Section 4 describes the differences between the experience of those separating from cohabitation compared to those separating from marriage. Section 5 examines to what extent observable differences between cohabitants and married women explain these differences, and provides evidence for the alternative mechanisms that can generate the differences. Section 6 concludes.

\section{Framework}

The aim of this section is to provide a framework for interpreting results on the consequences of separation for household income. This framework is from the woman's perspective. We consider the total income of the household in which the woman lives, including the income of all other individuals in the household. Total household income is assumed to be pooled within the household. In section 5.4 we consider the effect on our estimates of different assumptions about income pooling after relationship breakdown. Equvialization adjusts the amount of absolute income to account for differences in the number and age of household members to allow comparison across households.

We use superscripts $r \in\{M, C\}$ to denote whether the relationship was marriage or cohabitation, and the subscript $n \in\{T, S\}$ to denote whether currently together or single. Absolute income is denoted by $y$ and equivalized income by $\tilde{y}$. Therefore, for example, the equivalized income for a separated woman who was previously married, would be denoted by $\tilde{y}_{S}^{M}$. The fixed cost of separating is $\tau^{r}$. This fixed cost comprises both the financial and emotional costs of divorce, and is in addition to the loss of economies of scale and other benefits of being in a relationship which are common across cohabitation and marriage. We assume that the fixed cost of divorce is greater than the fixed cost of separating from cohabitation. The benefit of remaining together is given by $\kappa^{r}$. This is the other (financial and non-financial) benefit of remaining together that is not captured in household income and is partly determined by intrahousehold bargaining. The value of $\kappa^{r}$ can be positive or negative, with a negative value indicating a cost of remaining together 5

In line with Becker's (1973) theory of marriage, we expect any surviving marriage or cohabiting relationship to involve a surplus, with the division of household resources determined by conditions in the marriage

\footnotetext{
${ }^{4}$ The incidence of ongoing spousal maintenance payments (the English legal term for alimony) is very low in the BHPS, which matches findings in Miles and Probert (2009).

${ }^{5}$ The value of $\kappa^{r}$ may include health effects of being in a relationship, as documented by Averett et al. (2013), and may differ across relationship types.
} 
or relationship market, ensuring that both members of the couple want to stay in the relationship ${ }^{6}$ This is also consistent with the bargaining models of Manser and Brown (1980) and McElroy and Horney (1981), as well as in collective models of the household, as in Chiappori (1992). Hence, it is only when the benefits of being separated, net of the fixed cost of separation, are greater than the benefit of being together that we expect separation to occur. There may be differences in how the surplus is split within marriage compared to within cohabitation: Grossbard-Shechtman (1993) shows that cohabitants obtain a lower share of the relationship surplus within relationships, particularly because there is less spousal labor being exchanged.

The change in equivalized income on separation is given by:

$$
\Delta^{r}=\tilde{y}_{S}^{r}-\tilde{y}_{T}^{r}
$$

This means that separation occurs if

$$
\begin{aligned}
\tilde{y}_{S}^{r}-\tau^{r} & >\tilde{y}_{T}^{r}+\kappa^{r} \\
& \Leftrightarrow \tilde{y}_{S}^{r}-\tilde{y}_{T}^{r}>\tau^{r}+\kappa^{r} \\
& \Leftrightarrow \Delta^{r}>\tau^{r}+\kappa^{r}
\end{aligned}
$$

Among those who we observe separating, the mean income change is given by:

$$
\int_{\tau^{r}+\kappa^{r}}^{+\infty} \Delta^{r} d F_{\Delta^{r}}
$$

We use this notation and figure 1 to show the various selection and behavior effects. Panel (a) of figure 1 gives a stylized representation of the distribution of potential and observed changes in equivalized income for women on separation, $\Delta^{r}$. When separation occurs, household income falls due to the loss of the other partner's income. This fall in household income is offset by the change in household size and composition, with the extent of this offset determined by the economies of scale, and these combined effects determine the overall change in equivalized household income, $\Delta^{r}$. When equivalized household income falls on separation, $\Delta^{r}<0$. The solid red curve shows the distribution of $\Delta^{r}$ across different women. The vertical red line shows a particular value of $\kappa^{r}+\tau^{r}$. In reality, $\kappa^{r}$ will be drawn from a distribution of relationship benefits not reflected in household income. To the extent that benefits reflect the outcome of bargaining, the value of $\kappa^{r}$ will be affected by the outside options of each individual. Hence, we might expect that those women who have values of $\Delta^{r}$ in the left tail of the distribution will have lower values of $\kappa^{r}$. The relationship of a couple with a particular $\kappa^{r}$ will break down if the household income loss, $\Delta^{r}$, lies to the right of the value of $\kappa^{r}+\tau^{r}$ shown in the vertical line: this is the area where the cost of staying together is greater than the loss caused by separation and so the net benefits of marriage are negative. In this simple scenario, we would

\footnotetext{
${ }^{6}$ Adjustments to the division of household resources are limited to the extent that utility is transferable. Separation therefore occurs either when there is no surplus or when one partner is not able to transfer utility to compensate the other for remaining in the relationship.
} 
observe the distribution of changes in household income for those who actually separate to be drawn from the orange shaded truncated distribution: observed losses will be less than potential losses, for any given $\kappa^{r}$ and $\tau^{r}$.

Panel (b) of figure 1 introduces differences between marriage and cohabitation. The one-off additional cost of divorce $\tau^{M}$ which is greater than the cost of separation from cohabitation is not reflected in measures of changes in equivalized household income in our data. Instead, the additional costs of divorce shifts the vertical line to the right for those who are married, as shown in panel (b) of figure 1 . Further, the legal position of women on divorce is stronger than the position of those who were cohabiting because the law offers greater protection of income to those who divorce. This legal protection is typically a transfer from the man to the woman, improving the woman's outside option at the expense of the man. This shifts the distribution of changes in potential income for women to the right (to the blue dashed line). In addition, the woman's bargaining position within marriage is stronger, which may lead to an increase in $\kappa^{M}$. These direct effects that shift the vertical line and shift the distribution of changes generate a new truncated distribution for the observed change in income of those who divorce, shown by the hashed area. The average loss of equivalized income for women who are observed to divorce would therefore be less than the average loss for those who were cohabiting.

However, this simple analysis ignores various selection issues. Selection effects are induced by decisions at three distinct stages in relationship formation: first, for a couple who want to live together, there is a decision about whether to cohabit or to get married; second, there are decisions within the relationship about what investments and commitments to make into that relationship; and third, there is a decision about whether to separate or remain together. The latter two decisions are clearly ongoing decisions for any couple still together. The differential fixed costs of separation, $\tau^{r}$, will generate different selection effects at each stage of the relationship, and hence differences in the distribution of $\Delta^{r}$ for married and cohabiting couples.

The effect of the higher cost of divorce, $\tau^{M}$, is that we would expect that only couples with a higher financial (or other) benefit from being in a relationship will choose to marry. This means that the distribution of changes in household income, $\Delta^{M}$, for those who are married will be shifted left relative to the distribution for those who are cohabiting. Moreover, the higher cost of divorce may induce additional investments within marriage because the higher cost makes divorce less likely. This investment in marriage specific benefits will further shift the distribution of changes in income on divorce, $\Delta^{M}$, to the left, and possibly increase the non-financial benefits of marriage, $\kappa^{M}$. Finally, there may be differences in the extent to which couples who are married and cohabiting have recourse to social support networks in the event of relationship breakdown: for example, if married couples have less access to these social support networks (such as their parental homes), this will reinforce the leftward shift of the distribution of $\Delta^{M}$. For the same $\kappa^{r}$ and if we ignore 
the direct effect of differences in $\tau^{r}$ and the legal protection shown in panel (b), this leftward shift of the distribution of potential changes in household income for married couples would imply that the observed average household income loss on divorce would be greater than the average observed loss on separation from cohabitation. Panel (c) shows the combination of the leftward shift of the distribution due to selection alongside the direct change in $\tau^{M}$ and $\kappa^{M}$ from panel (b): the selection effect offsets the sharper truncation due to the direct effect of the larger $\tau^{M}$, and causes the average observed loss on divorce to be greater than for cohabitants.

It is not clear ex ante whether the selection effects outweighs the direct effects. The average change in observed household income on divorce could be less than or greater than the change in average household income after separation from cohabitation depending on whether the selection effects are larger or smaller than the direct truncation effects.

As shown below, we observe that, conditional on observables, the income loss is greater for those who were married than those who were cohabiting. This suggests that the selection effects shifting the distribution of potential losses on divorce to the left outweigh the direct effects: marriage matters. Under the assumption that $\tau^{M}>\tau^{C}$, a further conclusion we can draw is that the potential income loss of divorce for those who are married is greater than the potential income loss of separation for those who are cohabiting.

\section{Data}

We use panel data from the first fifteen waves of the British Household Panel Survey (BHPS), from 1991 to 2005.7 The first wave of this survey covered a nationally representative sample of all adults in each of around 5,000 households. This gave an initial sample of approximately 10,000 individuals. Where possible, all individuals in this initial sample have been followed since. When an original sample member (OSM) forms a new household, the new partner is interviewed while she or he remains part of that household. However, if this partner leaves the household, they are followed only if they have a child with an OSM, regardless of marital status. For this reason, the BHPS does not necessarily track both partners after a separation. All sample members who complete an interview provide wide-ranging information including incomes, demographic information and social attitudes. For more information about the BHPS data see Taylor et al (2007).

We restrict our attention to individuals who we observe undergoing a separation from their partner, considering both those who were married and cohabiting. We adopt a functional definition of separation, the point at which partners no longer live together, rather than the granting of an official divorce (in the

\footnotetext{
${ }^{7}$ In 2006, the House of Lords ruling on Miller and McFarlane changed the basis of financial protection on divorce, although there is uncertainty about how much this change was enforced and so we end our data period in 2005.
} 
spirit of Duncan and Hoffman, 1985) ${ }^{8}$ Where an individual has undergone more than one separation, each is treated as a separate record. We restrict attention to working age individuals (from 16 to 65 for men and from 16 to 60 for women), and exclude individuals residing in Scotland and Northern Ireland due to their differing legal regimes.

This leaves us with a sample of 390 divorces and 412 separations from cohabitation for women, the focus for this paper's results, along with 282 divorces and 300 separations from cohabitation for men 9 The 802 female separations cover 664 individuals: 100 women are observed experiencing two relationship breakdowns, 16 women experience three and two women experience four 10 Since these sample sizes are large relative to previous studies, we are able to examine the differing experiences of separations from marriage and cohabitation. Moreover, in $76 \%$ of separations from marriage and $75 \%$ of separations from cohabitation, we have household income data for at least three waves following the separation, so we are able to consider the longer term economic impact of divorce and the mechanisms which drive any recovery. The first year in which a couple is observed to be separated is denoted as $t=0$. We treat each separation as an independent observation.

One potential weakness of our dataset is attrition of members of separating couples. We see more female separations than male separations, a pattern which is often seen in longitudinal studies (Uhrig 2008). This differential attrition does not affect our main results comparing married and cohabiting women.

We also observe more separations from cohabitations than from marriage, but it is unclear whether this reflects differential attrition: there are more married than cohabiting couples in the population, but cohabiting couples are more likely to separate. If there were differential attrition related to individual characteristics that drive income paths or living arrangements then our results would be biased.

To examine the extent of this problem, we identify a sample of 'known separations': instances where we observe a couple together, and have a later observation of one partner after the relationship has broken down. Where we do not observe the woman in the post-breakdown state, she has either attritted or was not eligible to be followed ${ }^{11}$ In total there are 526 known divorces and 656 known separations from cohabitation. Of these women, 66 and 15 respectively attrit, 26 and 142 respectively are ineligible to be followed, and 44 and 87 respectively do not provide sufficient income or other information to be included in this examination of

\footnotetext{
${ }^{8}$ Separations from marriage are said to occur when an individual changes their status from 'married' to either 'separated', 'divorced' or 'living with someone'. We disregard partnerships that have ended through the death of a partner. Separations from cohabitation occur when an individual changes their status from 'living with someone' to 'never married', 'separated' or 'divorced', or their status remains 'living with someone' but the identity of that partner changes. In addition, we exclude any separations where the spouse's identity is not recorded as changing over the separation time.

${ }^{9}$ We do not require the separating partnership to have children, in contrast with Jenkins (2009).

${ }^{10}$ Of the 100 women who separate twice, 41 experience two cohabitations, 17 two marriages and the remainder one marriage and one cohabitation. Six women separate from three cohabitations, seven from two cohabitations and one marriage, and three from two marriages and one cohabitation. One woman separates from four cohabitations, and one from two cohabitations and two marriages.

${ }^{11}$ In all cases at least one member of the separating couple must respond at time $t=0$, otherwise we do not know if a couple has separated and attritted, or just attritted.
} 
attrition 12

An interviewee is ineligible to be followed if they have lived with an original sample member (OSM) but not had a child with the OSM. As fewer cohabitants than married women have children, there are more cohabiting women who are ineligible to be followed. Appendix table A1 shows average characteristics of these groups. Women ineligible to be followed have fewer children, higher education and are in shorter relationships on average than those who are eligible to be followed. They have higher personal labor income and equivalized household income, work more hours, and are less likely to be receiving benefits. These patterns are common across married and cohabiting women.

Appendix table A2 shows the results from a probit regression of actual attrition on pre-separation characteristics. Cohabiting women are less likely to attrit when they contribute a higher share of previous household income. For married women, lower education and receiving benefits is associated with slightly higher attrition. Overall, we gain some confidence in our results due to the low attrition rates, but we cannot test for attrition based on unobservable characteristics.

We measure economic well-being using household income. The BHPS allows us to split household income into individual labor, benefit and other income. Our variables of interest are household income, and the labor and benefit income of the individual undergoing the separation (all deflated to 2000 prices using the retail price index). We assume that income within the household is pooled before separation and so household income for each individual at time $t=-1$ is total household income 13 To control for the extra cost of having a larger household, household income is adjusted using the McClements (before housing costs) equivalence scale. We also provide robustness checks using alternative equivalization scales. Rather than just converting household income to income per head, the McClements adjustment acknowledges the economies of scale inherent in maintaining a household and differing costs of individuals of different ages. For example, adding a spouse to a household of one requires only the addition of $67 \%$ of the existing resources to keep the standard of living constant. The weights for children vary with their age. Clearly, as the economies of scale from sharing a household increase, the implied cost of divorce (and the removal of the economies of scale) will increase. As pointed out by Jarvis and Jenkins (1999), income changes for men following separation are likely to be more sensitive to this since their change in household size on divorce is generally greater.

One difficulty with equivalizing post-separation income is that individuals may be making payments to households which they are no longer part of. Our equivalization factors ignore this and assume that all income is spent within the household that the individual lives in. Ideally we would net off the transfers from

\footnotetext{
${ }^{12}$ That is, they never respond to questions regarding individual characteristics, so we are limited to information at the household level.

${ }^{13}$ If this were not the case and, for example, a woman had a less than $50 \%$ share of household income before separation, they may actually improve their income on separation. We would need to consider bargaining within the household to allow for this (see, for example, Manser and Brown 1980). Moreover, Grossbard-Shechtman (1993) argues that a cohabitant's bargaining power is lower than a spouse's bargaining power resulting in a cohabitant having a lower share of household income than a married woman. This hypothesis is consistent with Mukhopadhyay (2008).
} 
the individual's income before making the within-household equivalization, but data on the amount of these transfers is poor. In contrast, any transfer income received (including transfers from a former partner as spousal or child support) is included in our measure of household income ${ }^{14}$

We use various additional socioeconomic controls, including age, education level, home ownership, asset income and whether there are young children in the household. We attempt to capture differences in attitudes using a family values index constructed from an individual's response to various statements such as "the family suffers if a woman works full time" and "single parents are as good as couples", and mental health or happiness level is captured using an individual's score on the General Health Questionnaire (GHQ).

\section{Differing Experiences}

In this section, we present the raw data on differences in income through separation for cohabitants and married couples. To understand these differences, we report the differences in observable characteristics between those who are married and those who are cohabiting and we show how the raw differences are affected by controlling for these observable characteristics. In the next section, we explore the reasons for these differences.

Figures 2 and 3 show the income loss on separation for men and women, distinguishing by the marital status of the relationship. Figure 2 shows the path of log total household income (including income from all members of the household the individual resides with during that year) through separation, while Figure 3 shows the difference between men and women explicitly ${ }^{15}$ We show both equivalized and total household income.

The striking point about Figure 2 is the fall in income for women on separation. The second point is that for women, separation from cohabitation is associated with a smaller fall in household income and in equivalized income than separation from marriage. If, as suggested in footnote 13, cohabitants have lower bargaining power than married women, pre-separation household income will lead to overestimates of the living standard of cohabitants, and so the observed difference in the decline of income between married and cohabiting women is an underestimate of the true difference in the decline. Averaging across type of separation gives numbers in line with those in Jenkins (2009). For men, there is little difference between separation from marriage and from cohabitation, and relatively little change to income or equivalized income.

The difference in income between men and women on separation is shown more starkly in figure 3 , which shows the average difference in household income between men and women who were previously cohabiting

\footnotetext{
${ }^{14}$ The data does not distinguish between the source of transfers, so it is not possible to examine the amount of any transfer from a former partner, just whether any transfer from a former partner is reported. Furthermore, reports of receiving spousal maintenance payments may also include the receipt of child support.

${ }^{15}$ As discussed above, the panel is unbalanced and there is attrition of the sample post-separation. The numbers in the figure are the raw averages across all observations for that "time since separation."
} 
or married. The fall in income is smaller for men than for women: this is consistent with German evidence that within intact couples, men have more wealth than women (Grabka et al 2013). The difference is larger in equivalized income because it is more common for children to remain with their mother. The difference is less marked for separation from cohabitation than for divorce, and the difference declines over time as women's household income increases.

The obvious question raised by the raw data is to what extent are these differences driven by different characteristics of those who are married compared to those who are cohabiting, and indeed by the different characteristics of those who divorce from those who separate from cohabitation. Table 1 shows these differences in observable characteristics. Within our full sample of separating women, divorced women are older, have more children, have been in their relationship for longer, have greater household income and assets, and are more likely to be home owners. These characteristics are consistent with the theory of cohabitation proposed by Grossbard-Shechtman (1993): women with higher ability can provide higher value to a household and so are more likely to be married. They are less likely to have to sacrifice the commitment of marriage in order to find a higher quality partner and are more likely to obtain a higher share of the surplus within the relationship.

In table 2, we control for these observable characteristics through a fixed effects regression of the log equivalized income on indicators of the time since separation. The fixed effect absorbs differences in characteristics at the time of separation. The regressions are estimated separately for married and cohabiting women. Columns 1 and 3 show the effects of separation and the aftermath of separation on income: women who are married suffer a $55 \%$ fall in equivalized income on separation, whereas those who are cohabiting suffer a $15 \%$ fall. Further, the loss for married women is more persistent than for cohabiting women.

Columns 2 and 4 additionally include controls for observable characteristics that vary over time and can be controlled by women going through relationship breakdown. This allows us to examine what actions mitigate the income falls experienced. Controlling for changes in observable characteristics increases the differences observed in the basic regression. Repartnering appears to be a key mechanism for recovery, increasing equivalized household income by $41 \%$ and $38 \%$ for previously-married and cohabiting women respectively. Labor market participation also appears to aid recovery. When a woman has a child after separation, equivalized income falls, reflecting the change in the equivalization scale with little corresponding increase in household income.

Due to the importance of repartnering, columns 2 and 4 of table 2 include regressors for the different household structures that might exist. These include whether the individual is living with a new partner, with another adult who is related to them, or with an unrelated adult. Recovery is helped by living in households with more than one adult, but there are differences between former cohabitants and divorcees: in 
particular, former cohabitants benefit from living with related adults. We explore the differences in behavior following separation in more detail in section 5 below.

Table 2 highlights that the time path of recovery appears to differ for cohabitants compared to married women and that there are differences in the way observable characteristics affect each group. Tables 3 and 4 explore this difference for absolute and equivalized income. In both tables, columns 1, 3 and 5 show the difference in means between formerly married and cohabiting women at times $t=0, t=1$ and $t=2$, that is the three years immediately following relationship breakdown. Columns 2, 4 and 6 control for observable characteristics. In the presence of heterogeneous effects of cohabitation on changes in household income, the regression coefficient of interest represents a weighted average of the individual effects. To investigate this heterogeneity, we include the cohabiting indicator variable interacted with two key variables: whether the woman had a child aged under three at the time of separation (infant), and the relationship length (duration) 16

If it were the case that conditional on the observable characteristics, relationship status were randomly assigned across separating women, the coefficient on the cohabiting indicator variable would be an estimate of the causal effect of being a cohabitant on post-separation income. While some of the observable characteristics will reflect the selection issues referred to in section 2 above, unobservable characteristics affecting relationship status and post-separation income changes are likely to remain. These results should therefore be interpreted with some care, but by controlling for observable characteristics, we compare observationally similar married and cohabiting women.

Table 3 shows the persistent raw difference in the change in household income after relationship breakdown. The fall in cohabiting women's household income is $42 \%$ less than for married women, and still remains $33 \%$ less two years later. Controlling for observable characteristics shows that this change in income is greater for women with higher previous household income, and is less severe the higher the share of the previous household income was attributed to the woman. The fall in household income is greater for older women, and less severe for those coming out of longer relationships ${ }^{17}$ The difference between divorcees and former cohabitants is eliminated for women with an infant, but remains for other women. Table 4 shows similar results for the change in log equivalized household income. Again, the negative impact of relationship breakdown on household income is around $30 \%$ less for cohabiting women than married women: this estimate becomes statistically insignificant for women with an infant, but remains important for other

\footnotetext{
${ }^{16}$ The presence of an infant and relationship length are the strongest predictors of marital status in our sample. We included other interactions with the cohabitation dummy, but these had negligible effect on the magnitude of the cohabitation indicator coefficient. An alternative approach to examining this heterogeneity is to use propensity score matching techniques, which typically assign equal weight to each 'treated' observation. Results from kernel density matching and stratified matching using the control variables for the propensity score are similar to the headline coefficients on the cohabitation indicator, reflecting that the cohabiting women in our sample tend not to have a young child and are in shorter relationships on average. These matching results are available on request.

${ }^{17}$ These results are robust to including indicator variables for the 8 major groups of the 1990 Standard Occupational Classification.
} 
women, even after controlling for these observable characteristics, for the two years immediately following relationship breakdown.

The results in table 4 are potentially sensitive to the income equivalization scale used. The McClements (before housing) scale attaches a sliding scale of weights according to the age of children in a household. Other potential equivalization scales include the modified OECD scale (which assigns a higher weight to younger children), taking the square root of household size, or simply using per capita income. Appendix table A3 shows that these estimates are robust to using these three alternative scales. To further examine whether differences in the presence and number of children are driving the difference between marriage and cohabitation, appendix table A4 shows regression results for women with no children, one child, and more than one child at the time of relationship breakdown. Splitting the sample by demographic structure means equivalization is less important, so the dependent variable is the change in log absolute household income. The results show that the differential effect of cohabitation is concentrated amongst women with no children, with the general effect of a longer relationship only significant within this group. This further confirms that the differential effect of cohabitation is not driven by the fact that married women have more children than cohabiting women: it is particularly strong amongst the subgroup of women with no children. This group contains those pre-fertility as well as those whose children have left home - the "empty-nesters". When we look at the sample of those without children and who are aged above and below 40, it appears that the group that loses most on separation is married women who are over 40 and who do not have any children living at home 18

To support this regression analysis, we present an Oaxaca-Blinder decomposition of the change in log household absolute and equivalized incomes in table 5 . This decomposes the raw difference in household income changes into a portion explained by the different characteristics or endowments of married and cohabiting women and a portion that remains unexplained. For this analysis, the reference group is married women: we estimate the regression with controls as in tables 3 and 4 (excluding interactions) just for married women, and predict the change in income for cohabiting women using these coefficients. This predicted change is the amount of the raw difference explained by the different characteristics of cohabiting women. Panel A of table 5 shows this analysis for the change in absolute income. In years 0 and 1, a substantial proportion of the raw difference is unexplained by characteristics. In panel B, the same is shown for years 0 and 1 for equivalized household income: a large proportion of the difference is unexplained by the observable characteristics we control for.

By contrast to the results for women, there is little difference between the income loss on separation for cohabitants and married men. Any slight difference that exists in the raw data shown in figure 2 disappears

\footnotetext{
${ }^{18}$ However, the sample size becomes very small when we split the data further and so it is hard to make statistical statements about differential effects at this level.
} 
when we control for observable characteristics 19

\section{Support Mechanisms on Relationship Breakdown}

The results above suggest that the impact of relationship breakdown for married women is greater than for cohabiting women even when we control for observable characteristics. Moreover, if cohabiting women receive a lower share of resources within a relationship than married women, then our estimates of the differential impact of breakdown underestimate the actual difference. The question this raises is why the difference in the effect of separation on cohabiting women and married women should remain after controlling for observable characteristics. We analyze how much of the difference is driven by differences in the response of the two types of women to becoming separated, and to differences in the sources of income available to each. These differences can be interpreted as differences in access to support mechanisms including government transfers, labor market opportunities, and financial and emotional support from family and friends. We consider differences in the receipt of benefit income, in labor market activity and income, and in living arrangements after separation.

\subsection{Benefit Income}

Table 6 reports differences in the receipt of benefit income for women who cohabited compared to being married. Columns 1, 3 and 5 show that cohabiting women are, on average, around $9 \%$ less likely to be receiving benefits after relationship breakdown. After controlling for observable characteristics, this difference disappears: there is no significant difference in the receipt of benefit income. The reason for the higher benefit income observed for divorced women in the raw difference is because divorced women have more children than women who had been cohabiting.

\subsection{Labor Market Engagement}

There are two separate aspects to differences in labor market engagement between cohabitants and married women: engagement within the intact relationship and engagement after separation. Table 1 reports descriptive statistics by relationship status. Labor income is not significantly different across relationship type prior to separation. Cohabitants are no more likely to be participating in the labor market, but among those who participate, cohabitants do work somewhat longer hours. If we look further back before separation, there is some evidence that married women are less engaged with the labor market than cohabitants, consistent with Grossbard-Shechtman (1993). This may reflect cohabiting women's higher labor market attachment as a response to a higher relationship dissolution risk (Johnson and Skinner 1986) and reflect lower levels of exchange of spousal labor supply and exchange of income in cohabiting relationships (Grossbard-Shechtman

\footnotetext{
${ }^{19}$ These results are reported in appendix table A5 Results for different equivalization scales are available on request.
} 
1993). This results in a greater capacity for formerly married women to respond to the income shock of divorce or the prospect of divorce through increased labor market activity.

Table 7 reports differences in various measures of labor market outcomes after separation, looking at the change in labor income, at participation rates, and at hours worked for participants. Married and cohabiting women appear very similar in terms of labor market outcomes in the raw data. After controlling for observable characteristics, cohabiting women participate less than married women. Furthermore, previously cohabiting women with an infant work fewer hours than similar married women. On the other hand, there remains no significant difference in labor income across the two groups. Therefore, changes in labor market engagement cannot explain the differences in falls in household income across the two groups. Indeed, if formerly cohabiting women participate less and work fewer hours than married women, we would expect a larger fall in household income for cohabiting women.

\subsection{Repartnering and Living Arrangements}

An indirect way that women can maintain their household income after separation is through their choice of living arrangements. There is a choice of living alone, with a new partner, with related adults (typically parents) and with unrelated adults. If we assume complete income pooling within a household, then this can improve the woman's welfare. Figure 4 shows the proportions of married and cohabiting women in each of these categories at different time periods after separation. There are large differences in behavior after separation: previously married women are most likely to be living with new partners, while those previously cohabiting are more likely to be living with related or unrelated adults. Only $4 \%$ of divorced women return to living with their extended families immediately following separation, whereas $19 \%$ of cohabiting women return.

In table 8, we consider these differences conditioning on observable characteristics. The first panel shows the probability of living with another adult whether a new partner or not; the second panel shows the probability of living with a new partner; and the third shows the probability of living with other adults (family or other house mates). After controlling for observable characteristics, the difference in the propensity to live alone is reduced, but formerly cohabiting women are even more likely to live in a household with other adults who are not new partners. The key difference is that married women who do not live alone are more likely to repartner, whereas cohabiting women who do not live alone are more likely to be living with family or roommates.

Alongside these differences in living arrangements, table 2 above shows that these differences matter for how household income is affected by separation: on average, cohabiting women benefit from the financial support of their extended family in a way that married women do not. There are several mechanisms which might result in this differential reliance on social networks. First, there might be constraints imposed by the 
different legal and policy treatments of divorce and separation from cohabitation. Importantly, in England and Wales there is no legal protection for former cohabitants. In contrast, when a married couple divorces, both partners will have a claim on the couple's joint assets, namely the marital home. So a formerly married woman might be expected to have greater access to their former home than a woman who was cohabiting, and this might crowd out family support. One way to test this hypothesis is to consider whether cohabiting women are more likely to move house after relationship breakdown. Table 9 shows these comparisons. Around $48 \%$ of women move house on separation: there is no significant difference between marriage and cohabitation after controlling for observable characteristics. This is consistent with results from Grabka et al (2013), who find that there is no significant difference in asset holdings for women based on their marital status within relationship. It does not appear that differential access to the former family home is the reason that married women are less likely to rely on family for financial support.

An alternative explanation is that this difference in living arrangements may reflect differences in the social support networks available to women on relationship breakdown. The BHPS collects information about the parents of the interviewed adults in wave 11: this is after the majority of separations in our dataset have taken place 20 In order to investigate whether cohabiting women are more likely to return to their family due to greater proximity to their parents, we examine the cross section of all partnered women in wave 11. Appendix table A6 shows that, on average, cohabiting women are more likely to have at least one parent alive than married women. However, this is explained by differences in observable characteristics, in particular age. Conditional on having a parent alive, cohabiting women are no more likely than married women to live less than one hour from a parent and to see the parent on a weekly basis. Moreover, although cohabiting women are more likely to report receiving some help from parents ${ }^{21}$ this is, again, explained by age and the presence of children. There is no observable difference in the parental relationship of the two groups of women.

This does not rule out differences in unobservable characteristics of parental relationships which differ systematically between married women and cohabitants. There may be selection into marriage of women who no longer wish to rely on their extended family, and so if their relationship breaks down they are less likely to return. Women who marry may also be expressing a stronger preference for being in a coresidential relationship, and so repartner quickly if their marriage breaks down. Marriage itself, or divorce, may change the nature of the social support networks, both in terms of an individual's desire to rely on these methods and in terms of the attitudes of those within the networks: marriage may be a watershed moment in a woman's life which separates her from her extended family. This explanation is in contrast to existing evidence that cohabitants are less connected to their family and local community than those who are married (Eggebeen

\footnotetext{
${ }^{20}$ Including indicators for whether the woman's mother and father are alive (as reported in wave 11), and an indicator for whether the woman was born outside of the UK, in the regressions in table 8 does not change the results.

${ }^{21}$ This includes shopping, childcare, housework and financial help.
} 
2005).

\subsection{Income Sharing within the Household}

One potential difficulty with interpreting the result that cohabiting women are supported by moving in with other adults is that our analysis assumes complete income pooling within each household before and after separation, and this enables the calculation of equivalized household income. It is not clear that this assumption is reasonable when a woman lives with her parents after separation ${ }^{22}$ An alternative extreme would be to include only the income of the individual and any partner who is living in the house. This is implicitly assuming that there is no income sharing at all with extended family living in the house or with any unrelated adults.

Analogously to table 3 table 10 shows the difference between cohabitants and married women in the fall in their log equivalized family income on separation 23 The key point is that when we include only an individual's own income and the income of their new partner, there is no difference in the income loss on separation for those splitting from marriage and for those splitting from cohabitation. This reinforces the conclusion that the difference in the financial impact of relationship breakdown is due to differences in access to other networks of support rather than to the individual behavior or characteristics of the parties. Because this assumes no income sharing at all, this result provides a lower bound on the differential impact on household income of divorce and separation from cohabitation. The conclusion again is that selection effects into marriage and the effect of fewer options after separation, outweigh any direct effects of the legally privileged institution of marriage when it comes to protecting household income.

\section{Conclusions}

The aim of this paper was to explain the observed difference in income loss on separation for those who were cohabiting compared to those who were married. In the raw data, women who were cohabiting lose less on separation than those who were married. This is partly due to differences in observable characteristics, such as more children being present in marriage than in cohabitation, and married women who separate being older. However, even when we control for age, the presence of children and other characteristics, the income loss for women separating from marriage is found to be greater, and this difference is concentrated amongst women without children living at home. The reason is partly selection and partly differences in support options (perhaps reflecting differences in unobserved characteristics): cohabitants who separate are more likely to move in with other adults who are not their (new) partners and it is these other adults who

\footnotetext{
${ }^{22}$ There may also be differences between cohabitants and married couples in income sharing prior to separation, as discussed above.

${ }^{23}$ Robustness checks for different equivalization scales as well as comparable propensity score matching results are available on request.
} 
can provide financial support. This exposes a difference in the social support mechanisms used by married and cohabiting women when their relationships break down: cohabiting women are more likely to rely on their families for support, and to return to live with them after separation.

This support provided by the families of cohabitants arises if there is income sharing across extended family members who live together. If the only income available to the separated women is their own and the income of any new partner, then the difference in income loss disappears: it is the choice of living arrangements that drives the difference in the impact of separation on income for cohabiting and married women.

In terms of the effects of legal protection, the different living arrangements after separation is not explained by cohabitants being more likely to have to move house due to a lack of legal protection. However, the legally privileged institution of marriage may affect this difference in living arrangements: once a woman marries, she is seen not to require the support of her family. Instead since she is able to rely on those legal protections, the nature of those networks changes through the institution of marriage.

One conclusion suggested by our results is that cohabitants are less in need of legal protection than was previously thought, whereas existing protection for divorcees is less effective. However, a more nuanced conclusion takes account of the way the presence of children affects our conclusions: when children are present, there are similar levels of recovery for married and cohabiting women; when children are not present, the falls for married women are much worse. This group of women without children includes both women who have never had children and those whose children have left home. The lack of protection is particularly concerning for divorcees whose children have left home and whose options for further mitigating the losses may be limited. A second conclusion relates to the way that the cost of separating is mitigated for women: it is very difficult for women to recover their living standard without outside help regardless of marital status. For cohabitants, help is more likely to come from extended family; for divorced women, it is more likely to come from a new partner. The role of the state either through benefits or through enforcing child support and spousal maintenance payments appears to have limited impact, especially when children are not present.

\section{References}

[1] Aassve, Arnstein, Gianni Betti, Stefano Massuco, and Letizia Mencarini, "Marital disruption and economic well-being: a comparative analysis," Journal of the Royal Statistical Society-Series A, 2007, 170 (3). 
[2] Angrist, Joshua D., "Estimating the Labor Market Impact of Voluntary Military Service Using Social Security Data on Military Applicants", Econometrica, 1998, 66, 249-288.

[3] Avellar, S. and P.J. Smock, "The Economic Consequences of the Dissolution of Cohabiting Unions.," Journal of Marriage and Family, 2005, 67 (2), 13.

[4] Averett, S., Argys, L. and J Sorkin "In sickness and in health: an examination of relationship status and health using data from the Canadian National Public Health Survey"Review of Economics of the Household (2013) 11: 599-633

[5] Becker, Gary S. "A theory of marriage: Part I." The Journal of Political Economy (1973): 813-846.

[6] Bianchi, S M, L Subaiya, and J R Kahn, "The gender gap in the economic well-being of nonresident fathers and custodial mothers.," Demography, May 1999, 36 (2), 195-203.

[7] Chiappori, P.-A., "Collective labor supply and welfare," Journal of Political Economy, 1982,100 (3), 437-467.

[8] Duncan, Greg J. and Saul D. Hoffman, Economic consequences of marital instability, Chicago, IL: National Bureau of Economic Research, 1985.

[9] Eggebeen, D. J., "Cohabitation and exchanges of support," Social Forces, 2005, 83 (3), 1097-1110.

[10] Fisher, H, "Divorce property division laws and the decision to marry or cohabit," Journal of Law, Economics and Organization, 2012, 28 (4), 734-753.

[11] Fisher, H. and H. Low, "Who wins, who loses and who recovers from divorce?," in "Sharing Lives, Dividing Assets: An Interdisciplinary Study" edited by Jo Miles and Rebecca Probert. Hart Publishing (2009)

[12] Gadalla, Tahany M., "Impact of Marital Dissolution on Men's and Women's Incomes: A Longitudinal Study," Journal of Divorce and Remarriage, 2009, 50 (1), 55-65.

[13] Grabka, Markus M., Jan Marcus, and Eva Sierminska. "Wealth distribution within couples." Review of Economics of the Household (2013): 1-28.

[14] Gray, Matthew and Bruce Chapman, "Relationship break-down and the economic welfare of Australian mothers and their children," Australian Journal of Labour Economics, 2007, 10 (4), 253-277.

[15] Grossbard-Shechtman, Shoshana. "On the economics of marriage: a theory of marriage labor and divorce." Boulder, CO: Westview Press, 1993. 
[16] Haskey, J., "Cohabitation in Great Britain: Past, present and future trends - and attitudes." Population Trends, 2001, 96, 25-32

[17] Jarvis, Sarah and Stephen P. Jenkins, "Marital splits and income changes: evidence from the British Household Panel Survey," Population Studies, 1999, 53 (2).

[18] Jenkins, Stephen P., "Marital splits and income changes over the longer term," in M. Brynin and J. Ermisch. Changing Relationships. London: Routledge, 2009.

[19] Johnson, William R., and Jonathan Skinner. "Labor supply and marital separation." The American Economic Review (1986): 455-469.

[20] Manser, Marilyn and Murray Brown, "Marriage and Household Decision-Making: A Bargaining Analysis," International Economic Review, February 1980, 21 (1).

[21] Manting, Dorien and Anne Marthe Bouman, "Short- and Long-Term Economic Consequences of the Dissolution of Marital and Consensual Unions. The Example of the Netherlands," European Sociological Review, 2006, 22 (4), 413-429.

[22] McKeever, M. and N.H. Wolfinger, "Reexamining the economic costs of marital disruption for women," Social Science Quarterly, 2002, 82 (1).

[23] McElroy, M. and M. J. Horney, "Nash-bargained Household Decisions: Toward a Generalization of the Theory of Demand, " International Economic Review, 1981, 22 (2), 335-349.

[24] McManus, P.A. and T.A. DiPrete, "Losers and winners: The financial consequences of separation and divorce for men," American Sociological Review, 2001, 66 (2).

[25] Miles, J. and Probert, R, "Sharing Lives, Dividing Assets: An Interdisciplinary Study", Hart Publishing 2009

[26] Mukhopadhyay, S. "Do women value marriage more? The effect of obesity on cohabitation and marriage in the USA." Review of Economics of the Household 6, no. 2 (2008): 111-126.

[27] Smock, P.J., W.D. Manning, and Sanjiv Gupta, "The effect of marriage and divorce on women's economic well-being," American Sociological Review, 1999, 64 (6).

[28] Taylor, Marcia Freed, John Brice, Nick Buck, and Elaine Prentice-Lane, "British Household Panel Survey User Manual Volume A: Introduction, Technical Report and Appendices," 2007.

[29] Uhrig, S. C. Noah, "The Nature and Causes of Attrition in the British Household Panel Survey," ISER Working Paper, 2008, No. 5. 
[30] Uunk, W, "The Economic Consequences of Divorce for Women in the European Union: The Impact of Welfare State Arrangements," European Journal of Population, 2004, 20, 251-285.

[31] Voena, A, "Yours, mine and ours: do divorce laws affect the intertemporal behavior of married couples?", 2010. 
Figure 1: Distribution of equivalized income losses on separation

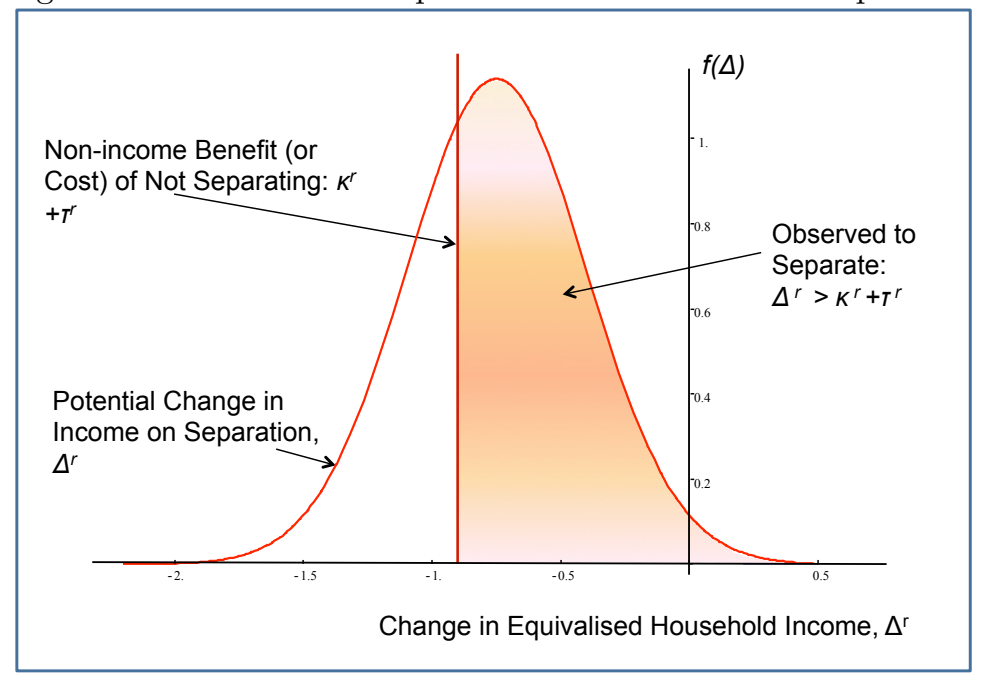

(a)

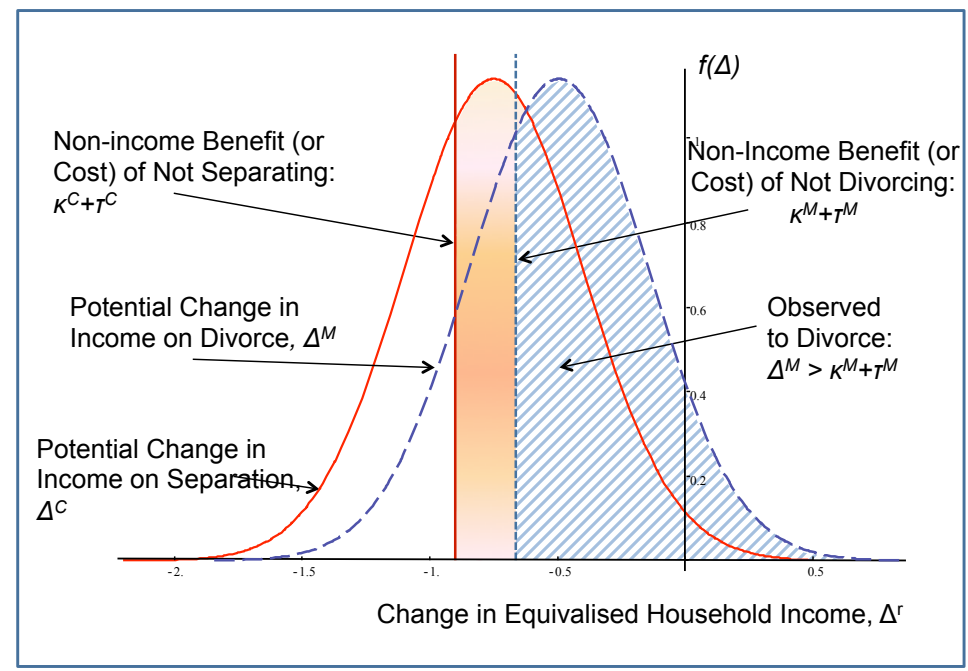

(b)

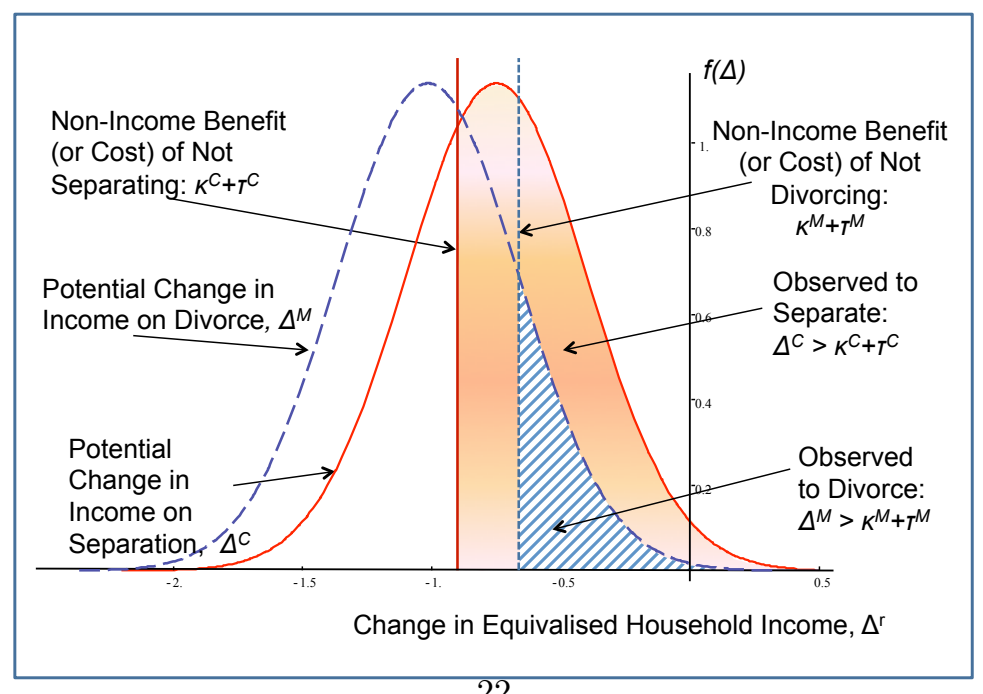

(c) 
Figure 2: Log household income from time of separation
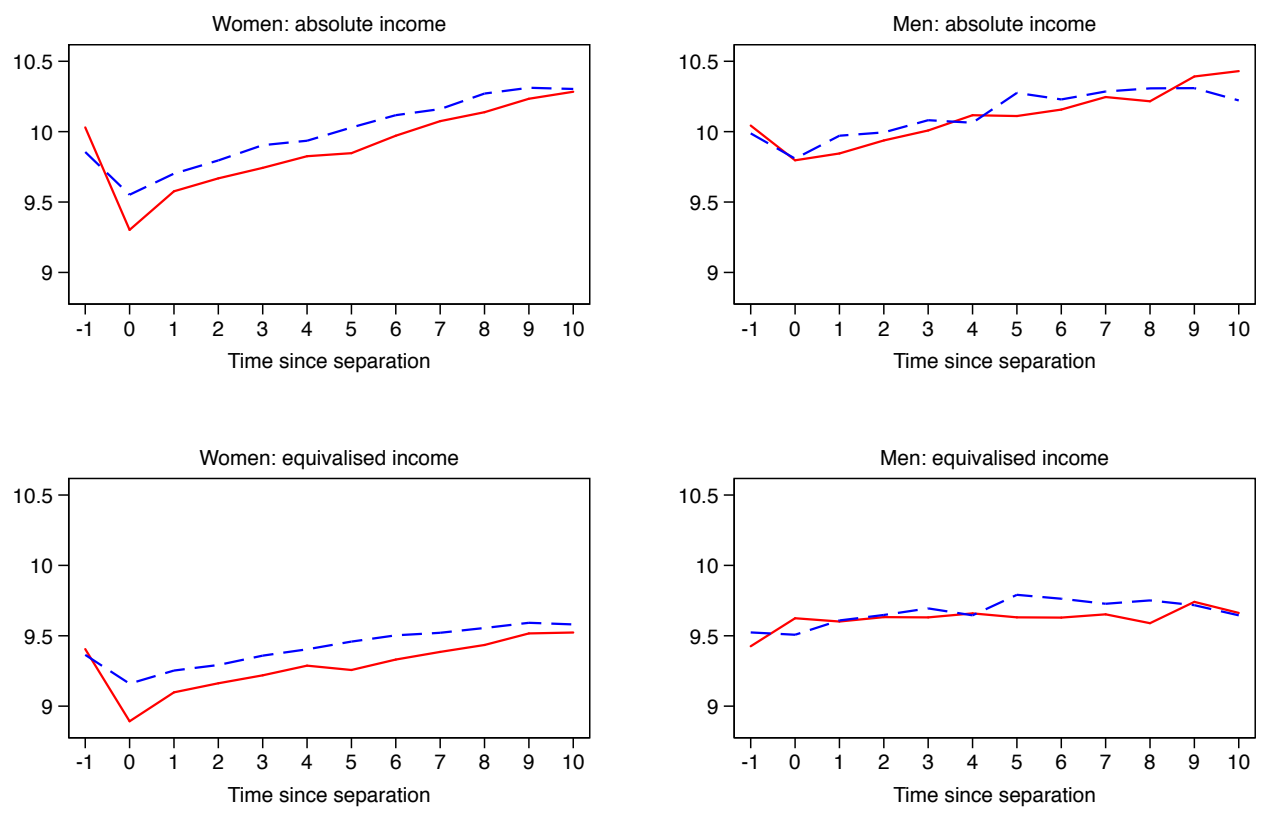

Married

Cohabiting

Graphs show average log absolute or equivalized household income for our BHPS separations sample after relationship breakdown. Time -1 is the last observed instance of a couple being together. 
Figure 3: Difference between men's and women's log household income
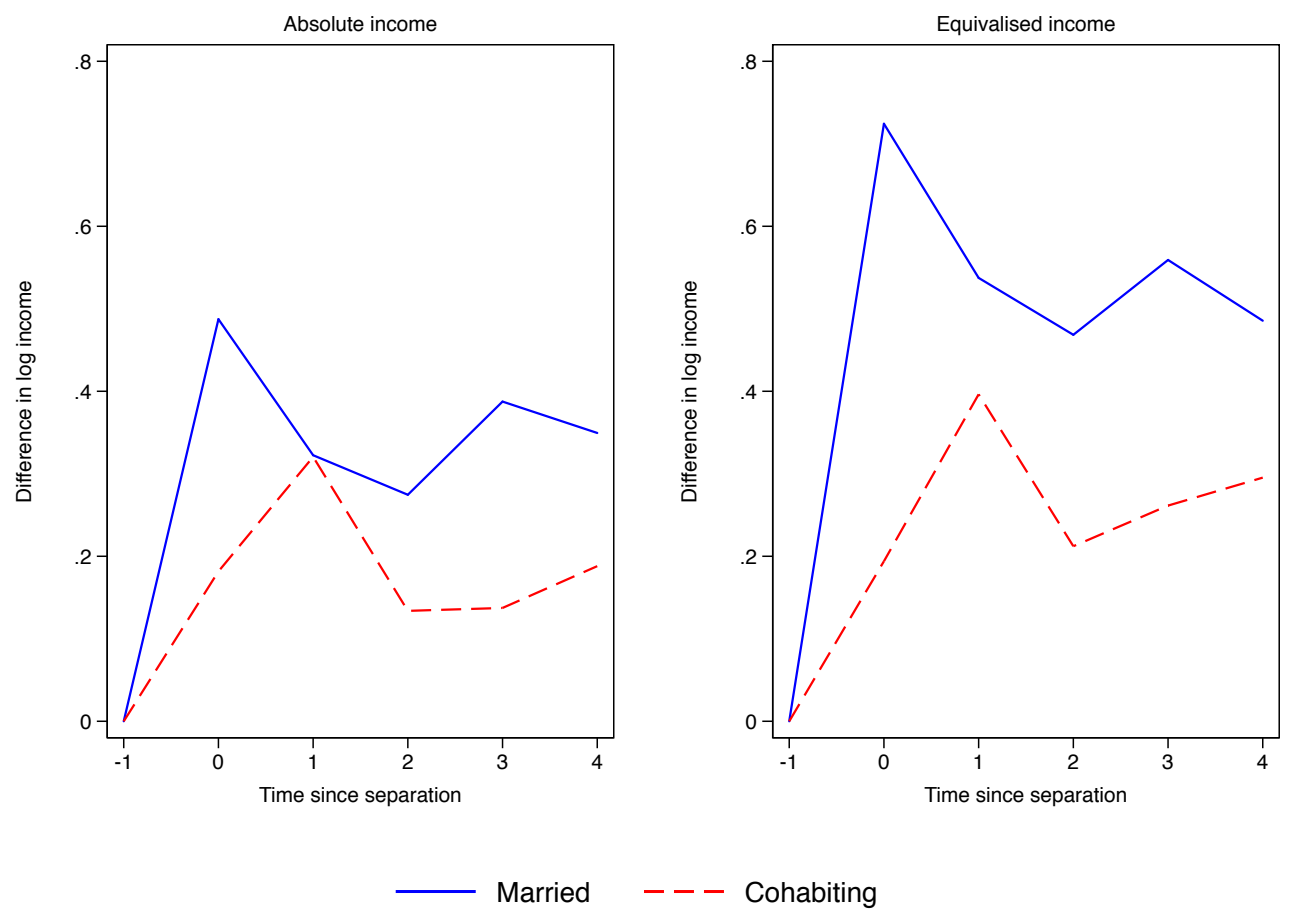

Graph shows the average of man's minus woman's log household income for couples where we observe both individuals post-breakdown. 
Table 1: Descriptive statistics in the period before separation

\begin{tabular}{|c|c|c|c|c|}
\hline \multirow[b]{2}{*}{ Variable } & \multicolumn{2}{|c|}{ Women } & \multicolumn{2}{|c|}{ Men } \\
\hline & Married & Cohabiting & Married & Cohabiting \\
\hline \multirow[t]{2}{*}{ Age } & 36.05 & 27.98 & 39.08 & 30.88 \\
\hline & $(8.84)$ & $(8.34)$ & $(9.60)$ & $(9.31)$ \\
\hline \multirow[t]{2}{*}{ Number of children } & 1.31 & 0.76 & 1.25 & 0.52 \\
\hline & $(1.21)$ & $(0.97)$ & $(1.14)$ & $(0.82)$ \\
\hline \multirow[t]{2}{*}{ Child under 3} & 0.21 & 0.19 & 0.19 & 0.17 \\
\hline & $(0.41)$ & $(0.39)$ & $(0.39)$ & $(0.38)$ \\
\hline \multirow[t]{2}{*}{ Any child } & 0.64 & 0.29 & 0.63 & 0.30 \\
\hline & $(0.48)$ & $(0.45)$ & $(0.48)$ & $(0.46)$ \\
\hline \multirow[t]{2}{*}{ Education } & 2.47 & 2.84 & 2.81 & 2.91 \\
\hline & $(1.58)$ & $(1.51)$ & $(1.64)$ & $(1.58)$ \\
\hline \multirow[t]{2}{*}{ GHQ score } & 0.40 & 0.35 & 0.36 & 0.32 \\
\hline & $(0.19)$ & $(0.18)$ & $(0.18)$ & $(0.15)$ \\
\hline \multirow[t]{2}{*}{ Family values index } & 0.15 & 0.12 & 0.22 & 0.16 \\
\hline & $(0.18)$ & $(0.15)$ & (0.22) & $(0.17)$ \\
\hline \multirow[t]{2}{*}{ Relationship duration } & 13.02 & 3.84 & 13.49 & 3.84 \\
\hline & (8.64) & (4.32) & $(8.75)$ & $(4.38)$ \\
\hline \multirow[t]{2}{*}{ Year separated } & 1998 & 1999 & 1998 & 1999 \\
\hline & $(3.88)$ & $(3.86)$ & (3.91) & (3.95) \\
\hline \multirow[t]{2}{*}{ Nonmarital cohabitation } & 0.77 & 1.00 & 0.78 & 1.00 \\
\hline & $(0.42)$ & $(0.00)$ & $(0.42)$ & $(0.00)$ \\
\hline \multirow[t]{2}{*}{ Labor force participation } & 0.69 & 0.68 & 0.87 & 0.83 \\
\hline & $(0.46)$ & $(0.47)$ & $(0.34)$ & $(0.37)$ \\
\hline \multirow[t]{2}{*}{ Hours worked per week } & 18.31 & 21.94 & 25.97 & 27.84 \\
\hline & (16.24) & (17.72) & (20.33) & $(18.37)$ \\
\hline \multirow[t]{2}{*}{ Labor income $(£)$} & 7245 & 7167 & 16108 & 13620 \\
\hline & $(9495)$ & (8378) & $(12659)$ & $(11109)$ \\
\hline \multirow[t]{2}{*}{ Benefit income $(£)$} & 1317 & 1510 & 745 & 501 \\
\hline & (1807) & (2652) & (2189) & $(1488)$ \\
\hline \multirow[t]{2}{*}{ Household income $(£)$} & 30014 & 25499 & 30877 & 28131 \\
\hline & $(20149)$ & $(18241)$ & (22292) & $(17095)$ \\
\hline \multirow[t]{2}{*}{ Equivalized income $(£)$} & 14901 & 14949 & 15107 & 16793 \\
\hline & $(10434)$ & $(12266)$ & $(10608)$ & $(13529)$ \\
\hline \multirow[t]{2}{*}{ Asset income $>£ 100$} & 0.12 & 0.07 & 0.21 & 0.11 \\
\hline & $(0.33)$ & $(0.26)$ & $(0.41)$ & $(0.31)$ \\
\hline \multirow[t]{2}{*}{ Home owner } & 0.74 & 0.48 & 0.78 & 0.55 \\
\hline & $(0.44)$ & $(0.50)$ & $(0.42)$ & $(0.50)$ \\
\hline \multirow[t]{2}{*}{ Income share of household income } & 0.31 & 0.37 & 0.57 & 0.53 \\
\hline & $(0.21)$ & $(0.23)$ & (0.22) & (0.22) \\
\hline Observations & 390 & 412 & 282 & 300 \\
\hline
\end{tabular}

Averages from BHPS separation sample for last intact relationship observation $(t=-1)$. Standard deviations in parentheses. Education scale from 0 (no qualification) to 6 (higher degree). All income amounts rebased to year $2000 £$. Equivalized income using McClements before housing costs scale, rescaled so a one adult household has an equivalence weight of 1 . 
Table 2: Fixed effects regressions: women's log equivalized household income

\begin{tabular}{lcccc}
\hline & \multicolumn{2}{c}{ Married } & \multicolumn{2}{c}{ Cohabiting } \\
& $(1)$ & $(2)$ & $(3)$ & $(4)$ \\
\hline \hline$t=0$ & $\mathbf{- 0 . 5 5 3}$ & $\mathbf{- 0 . 6 5 9}$ & $\mathbf{- 0 . 1 5 1}$ & $\mathbf{- 0 . 1 9 8}$ \\
& $(0.046)$ & $(0.048)$ & $(0.045)$ & $(0.042)$ \\
$t=1$ & $\mathbf{- 0 . 3 7 8}$ & $\mathbf{- 0 . 5 3 8}$ & $\mathbf{- 0 . 0 9 7}$ & $\mathbf{- 0 . 1 8 8}$ \\
& $(0.043)$ & $(0.046)$ & $(0.046)$ & $(0.046)$ \\
& $\mathbf{- 0 . 3 3 0}$ & $\mathbf{- 0 . 5 0 8}$ & -0.057 & $\mathbf{- 0 . 2 0 0}$ \\
$t=3$ & $(0.048)$ & $(0.052)$ & $(0.055)$ & $(0.053)$ \\
& $\mathbf{- 0 . 3 1 2}$ & $\mathbf{- 0 . 5 1 7}$ & -0.060 & $\mathbf{- 0 . 2 3 2}$ \\
$t>3$ & $(0.056)$ & $(0.060)$ & $(0.069)$ & $(0.066)$ \\
& $\mathbf{- 0 . 2 8 2}$ & $\mathbf{- 0 . 5 1 0}$ & -0.038 & $\mathbf{- 0 . 2 0 8}$ \\
Time trend & $(0.056)$ & $(0.058)$ & $(0.071)$ & $(0.068)$ \\
& $\mathbf{0 . 0 3 9}$ & $\mathbf{0 . 0 3 5}$ & $\mathbf{0 . 0 3 5}$ & $\mathbf{0 . 0 3 6}$ \\
Living Arrangements: & $(0.005)$ & $(0.004)$ & $(0.006)$ & $(0.006)$ \\
New partner & & & & \\
& & $\mathbf{0 . 4 0 6}$ & & $\mathbf{0 . 3 7 6}$ \\
Related adults & & $(0.042)$ & & $(0.040)$ \\
& & 0.071 & & $\mathbf{0 . 2 6 0}$ \\
Unrelated adults & & $(0.092)$ & & $(0.057)$ \\
& & 0.192 & & -0.074 \\
Has child & & $(0.098)$ & & $(0.077)$ \\
Participation & & $\mathbf{- 0 . 2 0 9}$ & & $\mathbf{- 0 . 2 0 6}$ \\
& & $(0.026)$ & & $(0.031)$ \\
Makes transfer & & $\mathbf{0 . 1 8 4}$ & & $\mathbf{0 . 2 6 9}$ \\
& & $(0.031)$ & & $(0.036)$ \\
Receives maintenance & & 0.051 & & 0.078 \\
& & $(0.071)$ & & $(0.059)$ \\
Observations & 0.003 & & $\mathbf{- 0 . 1 2 6}$ \\
Individuals & & $(0.039)$ & & $(0.049)$ \\
\hline \hline & & & & \\
& 5164 & 5164 & 4909 & 4909 \\
& 390 & 390 & 412 & 412 \\
\hline
\end{tabular}

Robust standard errors in parentheses. Bold indicates significance at 5\% level. All income amounts rebased to year 2000 $£$. McClements equivalization scale. Repartner denotes living with a new partner after relationship breakdown. 'Receives maintenance' indicates receipt of spousal maintenance payments (equivalent to alimony). 
Table 3: Change in women's log absolute household income on separation

\begin{tabular}{|c|c|c|c|c|c|c|}
\hline & \multicolumn{2}{|c|}{ Year 0} & \multicolumn{2}{|c|}{ Year 1} & \multicolumn{2}{|c|}{ Year 2} \\
\hline & (1) & $(2)$ & (3) & (4) & (5) & (6) \\
\hline Baseline change & $\begin{array}{l}-0.721 \\
\end{array}$ & & -0.420 & & "-0.313 & \\
\hline Cohabit & $\begin{array}{c}\mathbf{0 . 4 2 3} \\
(0.064)\end{array}$ & $\begin{array}{c}\mathbf{0 . 3 5 4} \\
(0.095)\end{array}$ & $\begin{array}{c}\mathbf{0 . 2 6 5} \\
(0.057)\end{array}$ & $\begin{array}{c}\mathbf{0 . 2 6 8} \\
(0.101)\end{array}$ & $\begin{array}{c}\mathbf{0 . 3 3 3} \\
(0.065)\end{array}$ & $\begin{array}{c}\mathbf{0 . 1 8 5} \\
(0.096)\end{array}$ \\
\hline Cohabit*Infant & & $\begin{array}{c}-\mathbf{- 0 . 4 3 4} \\
(0.132)\end{array}$ & & $\begin{array}{c}-\mathbf{- 0 . 3 8 2} \\
(0.133)\end{array}$ & & $\begin{array}{c}-\mathbf{- 0 . 3 8 3} \\
(0.157)\end{array}$ \\
\hline Cohabit*Duration & & $\begin{array}{l}-0.015 \\
(0.011)\end{array}$ & & $\begin{array}{l}-0.018 \\
(0.011)\end{array}$ & & $\begin{array}{l}-0.004 \\
(0.009)\end{array}$ \\
\hline Infant & & $\begin{array}{c}0.069 \\
(0.099)\end{array}$ & & $\begin{array}{c}0.192 \\
(0.100)\end{array}$ & & $\begin{array}{c}0.040 \\
(0.114)\end{array}$ \\
\hline Duration & & $\begin{array}{c}\mathbf{0 . 0 1 2} \\
(0.006)\end{array}$ & & $\begin{array}{c}\mathbf{0 . 0 1 4} \\
(0.006)\end{array}$ & & $\begin{array}{c}\mathbf{0 . 0 1 7} \\
(0.006)\end{array}$ \\
\hline Age & & $\begin{array}{c}-\mathbf{0 . 0 1 3} \\
(0.004)\end{array}$ & & $\begin{array}{c}-\mathbf{0 . 0 1 7} \\
(0.005)\end{array}$ & & $\begin{array}{c}-\mathbf{0 . 0 2 4} \\
(0.005)\end{array}$ \\
\hline Participation & & $\begin{array}{c}0.087 \\
(0.098)\end{array}$ & & $\begin{array}{c}0.014 \\
(0.093)\end{array}$ & & $\begin{array}{c}0.102 \\
(0.102)\end{array}$ \\
\hline Education & & $\begin{array}{c}0.018 \\
(0.021)\end{array}$ & & $\begin{array}{c}0.021 \\
(0.019)\end{array}$ & & $\begin{array}{c}\mathbf{0 . 0 5 3} \\
(0.021)\end{array}$ \\
\hline Hours & & $\begin{array}{c}\mathbf{0 . 0 0 8} \\
(0.003)\end{array}$ & & $\begin{array}{c}0.004 \\
(0.003)\end{array}$ & & $\begin{array}{l}-0.001 \\
(0.003)\end{array}$ \\
\hline Household income (£000) & & $\begin{array}{c}-\mathbf{- 0 . 0 1 3} \\
(0.003)\end{array}$ & & $\begin{array}{c}-\mathbf{0 . 0 1 1} \\
(0.002)\end{array}$ & & $\begin{array}{c}-\mathbf{- 0 . 0 1 4} \\
(0.003)\end{array}$ \\
\hline No. of children & & $\begin{array}{l}-0.034 \\
(0.030)\end{array}$ & & $\begin{array}{l}-0.022 \\
(0.030)\end{array}$ & & $\begin{array}{l}-0.043 \\
(0.033)\end{array}$ \\
\hline Income share & & $\begin{array}{l}\mathbf{1 . 1 7 6} \\
(0.179)\end{array}$ & & $\begin{array}{c}\mathbf{0 . 7 8 4} \\
(0.156)\end{array}$ & & $\begin{array}{c}\mathbf{0 . 8 5 3} \\
(0.171)\end{array}$ \\
\hline Observations & 777 & 777 & 690 & 690 & 627 & 627 \\
\hline
\end{tabular}

Dependent variable: change in log household income from last observation within relationship to indicated observation year post-relationship. Control variables are characteristics before relationship breakdown. Robust standard errors in parentheses. Bold indicates significance at $5 \%$ level. Additional controls in columns (2), (4) and (6): indicator variables for receipt of any benefit income and whether a home owner, year of separation, GHQ score and family values index. 
Table 4: Change in women's log equivalized household income on separation

\begin{tabular}{|c|c|c|c|c|c|c|}
\hline & \multicolumn{2}{|c|}{ Year 0} & \multicolumn{2}{|c|}{ Year 1} & \multicolumn{2}{|c|}{ Year 2} \\
\hline & (1) & (2) & (3) & (4) & (5) & (6) \\
\hline Baseline change & -0.507 & & -0.293 & & -0.216 & \\
\hline Cohabit & $\mathbf{0 . 3 0 4}$ & 0.325 & 0.160 & $\mathbf{0 . 2 4 4}$ & 0.159 & 0.094 \\
\hline Cohabit*Infant & & $\begin{array}{c}-\mathbf{0 . 2 8 1} \\
(0.123)\end{array}$ & & $\begin{array}{c}-0.266 \\
(0.124)\end{array}$ & & $\begin{array}{l}-0.205 \\
(0.156)\end{array}$ \\
\hline Cohabit*Duration & & $\begin{array}{l}-0.017 \\
(0.011)\end{array}$ & & $\begin{array}{l}-0.019 \\
(0.010)\end{array}$ & & $\begin{array}{l}-0.005 \\
(0.010)\end{array}$ \\
\hline Infant & & $\begin{array}{c}0.016 \\
(0.098)\end{array}$ & & $\begin{array}{c}0.099 \\
(0.097)\end{array}$ & & $\begin{array}{l}-0.048 \\
(0.107)\end{array}$ \\
\hline Duration & & $\begin{array}{c}\mathbf{0 . 0 1 6} \\
(0.005)\end{array}$ & & $\begin{array}{c}\mathbf{0 . 0 1 6} \\
(0.006)\end{array}$ & & $\begin{array}{c}\mathbf{0 . 0 1 6} \\
(0.006)\end{array}$ \\
\hline Age & & $\begin{array}{l}-0.004 \\
(0.004)\end{array}$ & & $\begin{array}{c}-\mathbf{0 . 0 0 9} \\
(0.004)\end{array}$ & & $\begin{array}{c}-\mathbf{0 . 0 1 2} \\
(0.005)\end{array}$ \\
\hline Participation & & $\begin{array}{c}0.006 \\
(0.091)\end{array}$ & & $\begin{array}{l}-0.040 \\
(0.086)\end{array}$ & & $\begin{array}{c}0.047 \\
(0.099)\end{array}$ \\
\hline Education & & $\begin{array}{c}0.025 \\
(0.020)\end{array}$ & & $\begin{array}{c}0.016 \\
(0.018)\end{array}$ & & $\begin{array}{c}0.027 \\
(0.020)\end{array}$ \\
\hline Hours & & $\begin{array}{c}\mathbf{0 . 0 0 8} \\
(0.003)\end{array}$ & & $\begin{array}{c}0.005 \\
(0.003)\end{array}$ & & $\begin{array}{c}0.000 \\
(0.003)\end{array}$ \\
\hline Household income (£000) & & $\begin{array}{c}-\mathbf{0 . 0 1 3} \\
(0.002)\end{array}$ & & $\begin{array}{c}-\mathbf{0 . 0 1 1} \\
(0.002)\end{array}$ & & $\begin{array}{c}-\mathbf{0 . 0 1 5} \\
(0.003)\end{array}$ \\
\hline No. of children & & $\begin{array}{l}-0.043 \\
(0.029)\end{array}$ & & $\begin{array}{l}-0.040 \\
(0.030)\end{array}$ & & $\begin{array}{c}-\mathbf{0 . 0 6 4} \\
(0.032)\end{array}$ \\
\hline Income share & & $\begin{array}{l}\mathbf{1 . 2 6 5} \\
(0.162)\end{array}$ & & $\begin{array}{c}\mathbf{0 . 8 2 1} \\
(0.145)\end{array}$ & & $\begin{array}{c}\mathbf{0 . 8 4 6} \\
(0.162)\end{array}$ \\
\hline Observations & 777 & 777 & 690 & 690 & 627 & 627 \\
\hline
\end{tabular}

Dependent variable: change in log household equivalized income from last observation within relationship to indicated observation year post-relationship. McClements equivalization scale used. Robust standard errors in parentheses. Bold indicates significance at $5 \%$ level. Additional controls in columns (2), (4) and (6) as in table 3. 
Table 5: Oaxaca-Blinder decomposition of change in household income

\begin{tabular}{lccc}
\hline & Year 0 & Year 1 & Year 2 \\
\hline \hline A: Change in log absolute income \\
Difference & $\mathbf{0 . 4 2 3}$ & $\mathbf{0 . 2 6 5}$ & $\mathbf{0 . 3 3 3}$ \\
& $(0.065)$ & $(0.058)$ & $(0.066)$ \\
Decomposition & & & \\
Endowments & $\mathbf{0 . 1 7 6}$ & 0.106 & $\mathbf{0 . 1 8 4}$ \\
& $(0.064)$ & $(0.064)$ & $(0.064)$ \\
Unexplained & $\mathbf{0 . 2 4 7}$ & $\mathbf{0 . 1 6 0}$ & $0.149+$ \\
& $(0.075)$ & $(0.079)$ & $(0.077)$
\end{tabular}

$\begin{array}{lccc}\text { B: Change in log equivalized income } \\ \text { Difference } & \mathbf{0 . 3 0 4} & \mathbf{0 . 1 6 0} & \mathbf{0 . 1 5 9} \\ & (0.061) & (0.054) & (0.064) \\ \text { Decomposition } & & & \\ \text { Endowments } & 0.075 & 0.016 & 0.091 \\ & (0.062) & (0.061) & (0.062) \\ \text { Unexplained } & \mathbf{0 . 2 2 9} & 0.144+ & 0.067 \\ & (0.072) & (0.075) & (0.078)\end{array}$

Observations $\quad 777 \quad 690 \quad 627$

Dependent variable: change in log household (equivalized) income from last observation within relationship to indicated observation year post-relationship. McClements equivalization scale used. Robust standard errors in parentheses. Bold indicates significance at $5 \%$ level; + indicates significance at $10 \%$ level. Controls used for decomposition as in table 3 .

Table 6: Women's benefit receipt after separation

\begin{tabular}{lcccccc}
\hline & \multicolumn{2}{c}{ Year 0} & \multicolumn{2}{c}{ Year 1 } & \multicolumn{2}{c}{ Year 2} \\
& $(1)$ & $(2)$ & $(3)$ & $(4)$ & $(5)$ & $(6)$ \\
\hline Baseline benefit receipt & 0.778 & & 0.788 & & 0.786 & \\
Cohabit & & & & & \\
& $\mathbf{0 . 0 8 9}$ & 0.052 & -0.067 & 0.072 & $\mathbf{- 0 . 0 8 4}$ & -0.005 \\
Cohabit*Infant & $(0.032)$ & $(0.049)$ & $(0.035)$ & $(0.054)$ & $(0.036)$ & $(0.062)$ \\
& & 0.015 & & -0.009 & & 0.005 \\
Cohabit*Duration & & $(0.040)$ & & $(0.053)$ & $(0.054)$ \\
Infant & & -0.005 & & 0.001 & 0.006 \\
& & $(0.005)$ & & $(0.005)$ & $(0.006)$ \\
Duration & & $\mathbf{0 . 0 6 4}$ & & $\mathbf{0 . 0 9 8}$ & $\mathbf{0 . 0 7 5}$ \\
& & $(0.029)$ & & $(0.040)$ & $(0.036)$ \\
\hline \hline
\end{tabular}

Dependent variable: indicator variable for receipt of any benefit income in indicated year post-relationship breakdown. Robust standard errors in parentheses. Bold indicates significance at $5 \%$ level. Controls in columns (2), (4) and (6) as in table 3. 
Table 7: Women's labor supply after separation

\begin{tabular}{|c|c|c|c|c|c|c|}
\hline & \multicolumn{2}{|c|}{ Year 0} & \multicolumn{2}{|c|}{ Year 1} & \multicolumn{2}{|c|}{ Year 2} \\
\hline & (1) & $(2)$ & $(3)$ & $(4)$ & $(5)$ & $(6)$ \\
\hline \multicolumn{7}{|c|}{ A: Change in own log labor income } \\
\hline Baseline change & 0.148 & & 0.162 & & 0.219 & \\
\hline Cohabit & $\begin{array}{c}0.051 \\
(0.078)\end{array}$ & $\begin{array}{c}0.159 \\
(0.126)\end{array}$ & $\begin{array}{c}0.089 \\
(0.109)\end{array}$ & $\begin{array}{c}0.083 \\
(0.172)\end{array}$ & $\begin{array}{c}0.230 \\
(0.119)\end{array}$ & $\begin{array}{c}\mathbf{0 . 3 6 4} \\
(0.173)\end{array}$ \\
\hline Cohabit*Infant & & $\begin{array}{l}-0.350 \\
(0.230)\end{array}$ & & $\begin{array}{l}-0.270 \\
(0.268)\end{array}$ & & $\begin{array}{l}-0.138 \\
(0.274)\end{array}$ \\
\hline Cohabit*Duration & & $\begin{array}{l}-0.000 \\
(0.011)\end{array}$ & & $\begin{array}{c}0.003 \\
(0.015)\end{array}$ & & $\begin{array}{l}-0.017 \\
(0.018)\end{array}$ \\
\hline Infant & & $\begin{array}{l}-0.038 \\
(0.124)\end{array}$ & & $\begin{array}{c}0.305 \\
(0.161)\end{array}$ & & $\begin{array}{c}0.093 \\
(0.164)\end{array}$ \\
\hline Duration & & $\begin{array}{c}0.000 \\
(0.008)\end{array}$ & & $\begin{array}{l}-0.003 \\
(0.009)\end{array}$ & & $\begin{array}{c}0.004 \\
(0.011)\end{array}$ \\
\hline B: Labor force $p$ & rticipati & & & & & \\
\hline Baseline rate & 0.701 & & 0.708 & & 0.650 & \\
\hline Cohabit & $\begin{array}{l}-0.040 \\
(0.033)\end{array}$ & $\begin{array}{c}-\mathbf{0 . 1 1 6} \\
(0.042)\end{array}$ & $\begin{array}{l}-0.043 \\
(0.035)\end{array}$ & $\begin{array}{c}\mathbf{- 0 . 1 5 4} \\
(0.052)\end{array}$ & $\begin{array}{c}0.001 \\
(0.038)\end{array}$ & $\begin{array}{l}-0.094 \\
(0.060)\end{array}$ \\
\hline Cohabit*Infant & & $\begin{array}{l}-0.040 \\
(0.071)\end{array}$ & & $\begin{array}{l}-0.096 \\
(0.083)\end{array}$ & & $\begin{array}{l}-0.099 \\
(0.090)\end{array}$ \\
\hline Cohabit*Duration & & $\begin{array}{c}0.007 \\
(0.004)\end{array}$ & & $\begin{array}{c}\mathbf{0 . 0 1 0} \\
(0.004)\end{array}$ & & $\begin{array}{c}0.006 \\
(0.006)\end{array}$ \\
\hline Infant & & $\begin{array}{l}-0.017 \\
(0.051)\end{array}$ & & $\begin{array}{c}0.020 \\
(0.057)\end{array}$ & & $\begin{array}{l}-0.021 \\
(0.058)\end{array}$ \\
\hline Duration & & $\begin{array}{l}-0.002 \\
(0.003)\end{array}$ & & $\begin{array}{l}-0.003 \\
(0.003)\end{array}$ & & $\begin{array}{l}-0.004 \\
(0.004)\end{array}$ \\
\hline C: Hours of worl & 19310 & & 19365 & & 18452 & \\
\hline Cohabit & $\begin{array}{c}1.742 \\
(1.269)\end{array}$ & $\begin{array}{l}-1.369 \\
(1.811)\end{array}$ & $\begin{array}{c}1.670 \\
(1.331)\end{array}$ & $\begin{array}{l}-2.899 \\
(1.900)\end{array}$ & $\begin{array}{c}2.180 \\
(1.399)\end{array}$ & $\begin{array}{l}-1.893 \\
\text { (2.092) }\end{array}$ \\
\hline Cohabit*Infant & & $\begin{array}{l}-4.477 \\
(2.030)\end{array}$ & & $\begin{array}{l}-5.221 \\
(2.204)\end{array}$ & & $\begin{array}{r}-4.779 \\
(2.597)\end{array}$ \\
\hline Cohabit*Duration & & $\begin{array}{c}0.133 \\
(0.154)\end{array}$ & & $\begin{array}{l}0.168 \\
(0.178)\end{array}$ & & $\begin{array}{c}0.210 \\
(0.209)\end{array}$ \\
\hline Infant & & $\begin{array}{c}1.125 \\
(1.542)\end{array}$ & & $\begin{array}{l}-0.642 \\
\text { (1.622) }\end{array}$ & & $\begin{array}{l}-1.196 \\
(1.798)\end{array}$ \\
\hline Duration & & $\begin{array}{l}-0.015 \\
(0.099)\end{array}$ & & $\begin{array}{l}-0.119 \\
(0.104)\end{array}$ & & $\begin{array}{l}-0.018 \\
(0.122)\end{array}$ \\
\hline
\end{tabular}

Robust standard errors in parentheses. Bold indicates significance at $5 \%$ level. Controls in columns (2), (4) and (6) as in table 3 . 
Table 8: Women's living arrangements after separation

\begin{tabular}{|c|c|c|c|c|c|c|}
\hline & \multicolumn{2}{|c|}{ Year 0} & \multicolumn{2}{|c|}{ Year 1} & \multicolumn{2}{|c|}{ Year 2} \\
\hline & (1) & $(2)$ & $(3)$ & $(4)$ & $(5)$ & $(6)$ \\
\hline \multicolumn{7}{|c|}{ A: Live with others (partner or other adults) } \\
\hline Baseline rate & 0.310 & & 0.374 & & 0.443 & \\
\hline \multirow[t]{2}{*}{ Cohabit } & 0.089 & 0.065 & 0.124 & 0.162 & 0.110 & 0.048 \\
\hline & $(0.034)$ & $(0.065)$ & $(0.038)$ & $(0.068)$ & $(0.040)$ & $(0.071)$ \\
\hline \multirow[t]{2}{*}{ Cohabit*Infant } & & -0.221 & & -0.240 & & -0.172 \\
\hline & & $(0.077)$ & & $(0.094)$ & & $(0.101)$ \\
\hline \multirow[t]{2}{*}{ Cohabit*Duration } & & -0.008 & & -0.017 & & -0.007 \\
\hline & & $(0.006)$ & & $(0.006)$ & & $(0.007)$ \\
\hline \multirow[t]{2}{*}{ Infant } & & -0.020 & & 0.050 & & 0.016 \\
\hline & & $(0.065)$ & & $(0.073)$ & & $(0.076)$ \\
\hline \multirow[t]{2}{*}{ Duration } & & 0.007 & & 0.012 & & 0.012 \\
\hline & & $(0.004)$ & & $(0.004)$ & & $(0.004)$ \\
\hline \multicolumn{7}{|l|}{ B: Repartners } \\
\hline Baseline rate & 0.214 & & 0.329 & & 0.396 & \\
\hline \multirow[t]{2}{*}{ Cohabit } & -0.100 & -0.176 & -0.061 & -0.044 & 0.031 & -0.047 \\
\hline & $(0.027)$ & $(0.058)$ & $(0.035)$ & $(0.068)$ & (0.039) & (0.073) \\
\hline \multirow[t]{2}{*}{ Cohabit*Infant } & & -0.036 & & -0.203 & & -0.124 \\
\hline & & (0.062) & & $(0.087)$ & & (0.102) \\
\hline \multirow[t]{2}{*}{ Cohabit*Duration } & & 0.009 & & -0.002 & & 0.004 \\
\hline & & $(0.006)$ & & $(0.006)$ & & $(0.007)$ \\
\hline \multirow[t]{2}{*}{ Infant } & & -0.024 & & 0.037 & & 0.030 \\
\hline & & $(0.059)$ & & (0.072) & & $(0.075)$ \\
\hline \multirow[t]{2}{*}{ Duration } & & 0.001 & & 0.007 & & 0.006 \\
\hline & & $(0.003)$ & & $(0.004)$ & & $(0.004)$ \\
\hline \multicolumn{7}{|c|}{ C: Lives with other adults } \\
\hline Baseline rate & 0.096 & & 0.044 & & 0.046 & \\
\hline \multirow[t]{2}{*}{ Cohabit } & 0.189 & 0.241 & 0.184 & 0.205 & 0.079 & 0.094 \\
\hline & $(0.027)$ & $(0.050)$ & $(0.025)$ & $(0.044)$ & (0.022) & $(0.042)$ \\
\hline \multirow[t]{2}{*}{ Cohabit*Infant } & & -0.185 & & -0.037 & & -0.048 \\
\hline & & $(0.056)$ & & $(0.058)$ & & $(0.047)$ \\
\hline \multirow[t]{2}{*}{ Cohabit*Duration } & & -0.017 & & -0.015 & & -0.011 \\
\hline & & $(0.004)$ & & $(0.004)$ & & $(0.003)$ \\
\hline \multirow[t]{2}{*}{ Infant } & & 0.004 & & 0.013 & & -0.014 \\
\hline & & $(0.037)$ & & $(0.024)$ & & $(0.025)$ \\
\hline \multirow[t]{2}{*}{ Duration } & & 0.006 & & 0.005 & & 0.006 \\
\hline & & $(0.003)$ & & $(0.003)$ & & $(0.002)$ \\
\hline
\end{tabular}

Robust standard errors in parentheses. Bold indicates significance at $5 \%$ level. Controls in columns (2), (4) and (6) as in table 3 . 
Figure 4: Women's living arrangements after relationship breakdown
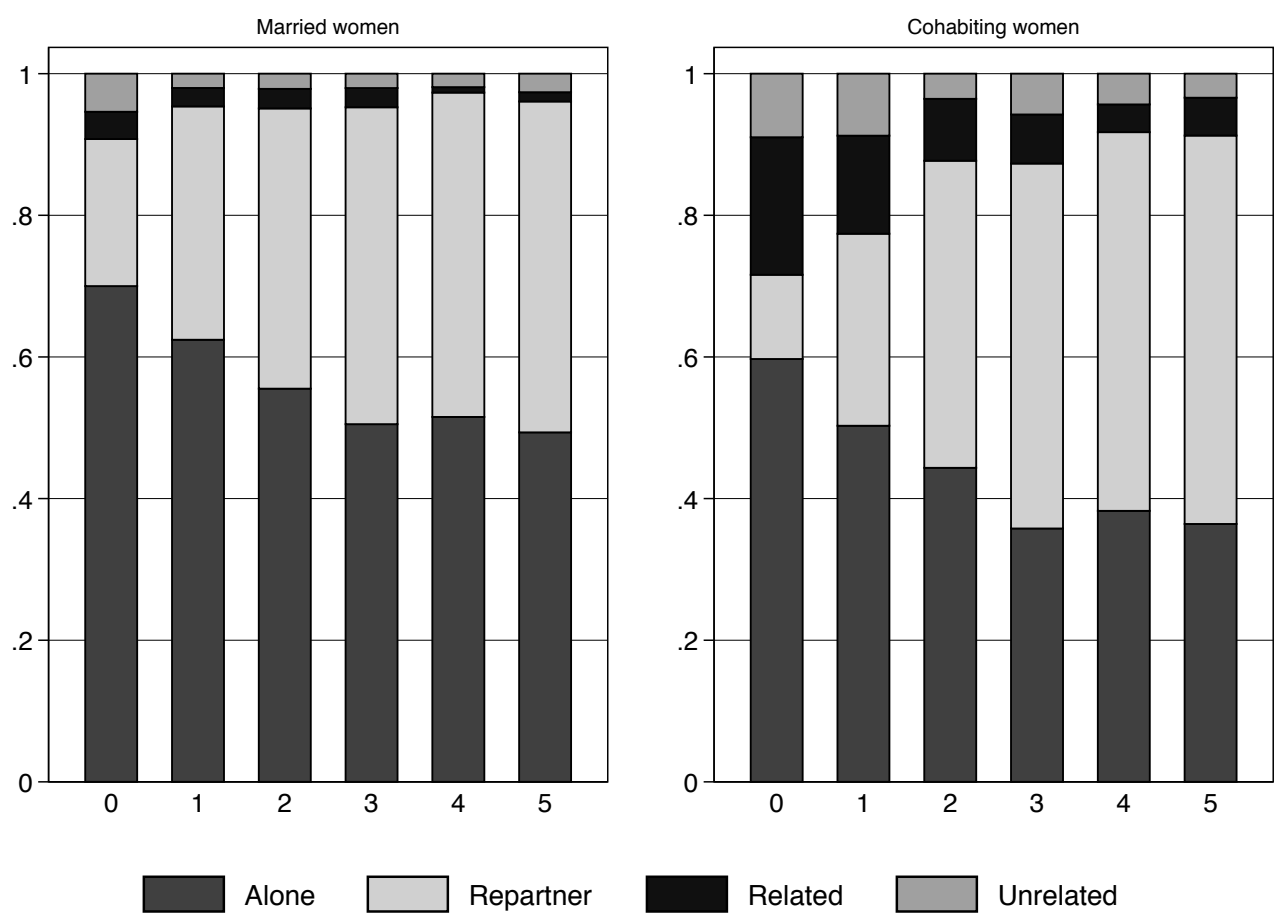

Table 9: Moved house since separation

\begin{tabular}{lcccccc}
\hline & \multicolumn{2}{c}{ Year 0 } & \multicolumn{2}{c}{ Year 1 } & \multicolumn{2}{c}{ Year 2 } \\
& $(1)$ & $(2)$ & $(3)$ & $(4)$ & $(5)$ & $(6)$ \\
\hline \hline Baseline rate & 0.452 & & 0.541 & & 0.607 & \\
& & & & & & \\
Cohabit & 0.062 & 0.106 & $\mathbf{0 . 0 9 0}$ & 0.058 & $\mathbf{0 . 0 8 4}$ & 0.027 \\
& $(0.036)$ & $(0.066)$ & $(0.037)$ & $(0.070)$ & $(0.038)$ & $(0.070)$ \\
Cohabit*Infant & & $\mathbf{- 0 . 1 8 3}$ & & -0.103 & & -0.053 \\
& & $(0.091)$ & & $(0.098)$ & $(0.100)$ \\
Cohabit*Duration & & $\mathbf{- 0 . 0 1 6}$ & -0.008 & -0.004 \\
& & $(0.006)$ & & $(0.007)$ & $(0.007)$ \\
Infant & & 0.036 & 0.049 & 0.091 \\
& & $(0.071)$ & $(0.073)$ & $(0.073)$ \\
Duration & & 0.006 & & 0.005 & & $\mathbf{0 . 0 1 0}$ \\
& & $(0.004)$ & & $(0.004)$ & $(0.004)$ \\
\hline \hline
\end{tabular}

Robust standard errors in parentheses. Bold indicates significance at $5 \%$ level. Controls in columns (2), (4) and (6) as in table 3 . 
Table 10: Change in women's log equivalized family income on separation

\begin{tabular}{lcccccc}
\hline & \multicolumn{2}{c}{ Year 0} & \multicolumn{2}{c}{ Year 1 } & \multicolumn{2}{c}{ Year 2 } \\
& $(1)$ & $(2)$ & $(3)$ & $(4)$ & $(5)$ & $(6)$ \\
\hline \hline Baseline change & -0.677 & & -0.378 & & -0.302 & \\
& & & & & & \\
Cohabit & 0.024 & -0.005 & -0.018 & 0.099 & 0.056 & -0.061 \\
& $(0.077)$ & $(0.114)$ & $(0.072)$ & $(0.137)$ & $(0.093)$ & $(0.137)$ \\
Cohabit*Infant & & 0.062 & & -0.209 & & 0.124 \\
& & $(0.147)$ & & $(0.153)$ & $(0.182)$ \\
Cohabit*Duration & & -0.009 & -0.010 & 0.006 \\
& & $(0.012)$ & & $(0.012)$ & $(0.013)$ \\
Infant & & -0.010 & & 0.047 & -0.070 \\
& & $(0.115)$ & & $(0.119)$ & $(0.125)$ \\
Duration & $\mathbf{0 . 0 2 0}$ & $\mathbf{0 . 0 2 3}$ & 0.012 \\
& & $(0.007)$ & $(0.007)$ & $(0.009)$ \\
\hline \hline
\end{tabular}

Dependent variable: change in log family (individual plus any partner) equivalized income from last observation within relationship to indicated observation year post-relationship. McClements equivalization scale used. Robust standard errors in parentheses. Bold indicates significance at $5 \%$ level. Controls in columns (2), (4) and (6) as in table 3. 
Table A1: Summary statistics before breakdown, by attrition and follow status

\begin{tabular}{|c|c|c|c|c|c|c|}
\hline & \multicolumn{3}{|c|}{ Married } & \multicolumn{3}{|c|}{ Cohabiting } \\
\hline & Followed & Attrit & Not followed & Followed & Attrit & Not followed \\
\hline \multirow[t]{2}{*}{ Age } & 36.05 & 34.44 & 32.50 & 27.98 & 27.00 & 26.39 \\
\hline & $(8.84)$ & $(9.65)$ & $(9.11)$ & $(8.34)$ & (11.78) & $(7.47)$ \\
\hline \multirow[t]{2}{*}{ Number of children } & 1.31 & 1.29 & 0.35 & 0.76 & 1.00 & 0.34 \\
\hline & $(1.21)$ & $(0.99)$ & $(0.63)$ & $(0.97)$ & $(1.07)$ & $(0.69)$ \\
\hline \multirow[t]{2}{*}{ Child under 3} & 0.21 & 0.27 & 0.08 & 0.19 & 0.27 & 0.07 \\
\hline & $(0.41)$ & $(0.45)$ & $(0.27)$ & $(0.39)$ & $(0.46)$ & $(0.26)$ \\
\hline \multirow[t]{2}{*}{ Any child } & 0.64 & 0.61 & 0.23 & 0.29 & 0.53 & 0.20 \\
\hline & $(0.48)$ & $(0.49)$ & $(0.43)$ & $(0.45)$ & $(0.52)$ & $(0.40)$ \\
\hline \multirow[t]{2}{*}{ Education } & 2.47 & 2.03 & 2.88 & 2.84 & 2.00 & 3.10 \\
\hline & $(1.58)$ & $(1.41)$ & $(1.75)$ & $(1.51)$ & (1.69) & $(1.51)$ \\
\hline \multirow[t]{2}{*}{ GHQ score } & 0.40 & 0.36 & 0.37 & 0.35 & 0.36 & 0.35 \\
\hline & $(0.19)$ & $(0.17)$ & $(0.18)$ & $(0.18)$ & $(0.18)$ & $(0.17)$ \\
\hline \multirow[t]{2}{*}{ Family values index } & 0.15 & 0.17 & 0.15 & 0.12 & 0.15 & 0.14 \\
\hline & $(0.18)$ & (0.22) & $(0.20)$ & $(0.15)$ & $(0.18)$ & $(0.16)$ \\
\hline \multirow[t]{2}{*}{ Relationship duration } & 12.94 & 10.45 & 5.50 & 3.81 & 4.60 & 2.43 \\
\hline & $(8.59)$ & (8.22) & $(4.77)$ & $(4.12)$ & $(5.04)$ & (2.52) \\
\hline \multirow[t]{2}{*}{ Year of separation } & 1998 & 1998 & 2000 & 1999 & 1997 & 2000 \\
\hline & $(3.88)$ & $(4.53)$ & $(3.30)$ & $(3.86)$ & $(4.76)$ & $(3.50)$ \\
\hline \multirow[t]{2}{*}{ Labor force participation } & 0.69 & 0.65 & 0.96 & 0.68 & 0.47 & 0.68 \\
\hline & $(0.46)$ & $(0.48)$ & $(0.20)$ & $(0.47)$ & $(0.52)$ & $(0.47)$ \\
\hline \multirow[t]{2}{*}{ Hours worked } & 18.31 & 18.80 & 31.77 & 21.94 & 16.80 & 24.14 \\
\hline & $(16.24)$ & $(16.34)$ & (13.03) & (17.72) & $(18.88)$ & $(17.30)$ \\
\hline \multirow[t]{2}{*}{ Labor income $(£)$} & 7245 & 7093 & 15538 & 7167 & 4215 & 8191 \\
\hline & $(9495)$ & $(23896)$ & $(18198)$ & (8378) & (6053) & $(7701)$ \\
\hline \multirow[t]{2}{*}{ Receives benefits } & 0.78 & 0.86 & 0.38 & 0.61 & 0.67 & 0.46 \\
\hline & $(0.42)$ & $(0.35)$ & $(0.50)$ & $(0.49)$ & $(0.49)$ & $(0.50)$ \\
\hline \multirow[t]{2}{*}{ Eq. household income $(£)$} & 14901 & 13354 & 24679 & 14949 & 13300 & 19057 \\
\hline & $(10434)$ & $(16564)$ & $(14657)$ & $(12266)$ & $(12448)$ & $(17846)$ \\
\hline \multirow[t]{2}{*}{ Asset income $>£ 100$} & 0.20 & 0.12 & 0.19 & 0.10 & 0.07 & 0.11 \\
\hline & $(0.40)$ & (0.33) & $(0.40)$ & $(0.30)$ & $(0.26)$ & $(0.32)$ \\
\hline \multirow[t]{2}{*}{ Home owner } & 0.74 & 0.67 & 0.73 & 0.48 & 0.60 & 0.56 \\
\hline & $(0.44)$ & $(0.48)$ & $(0.45)$ & $(0.50)$ & $(0.51)$ & $(0.50)$ \\
\hline \multirow[t]{2}{*}{ Share of household income } & 0.31 & 0.31 & 0.35 & 0.37 & 0.21 & 0.36 \\
\hline & $(0.21)$ & $(0.23)$ & $(0.20)$ & $(0.24)$ & $(0.17)$ & $(0.19)$ \\
\hline Observations & 390 & 66 & 26 & 412 & 15 & 142 \\
\hline
\end{tabular}

Averages from BHPS separation sample for last intact relationship observation $(t=-1)$. Standard deviations in parentheses. Education scale from 0 (no qualification) to 6 (higher degree). All income amounts rebased to year $2000 £$. Equivalized income using McClements before housing costs scale, rescaled so a one adult household has an equivalence weight of 1 . 
Table A2: Predictors of attrition

\begin{tabular}{|c|c|c|c|c|}
\hline & \multicolumn{2}{|c|}{ Women } & \multicolumn{2}{|c|}{ Men } \\
\hline & Married & Cohabiting & Married & Cohabiting \\
\hline \multirow[t]{2}{*}{ Age } & 0.000 & -0.001 & 0.003 & 0.000 \\
\hline & $(0.003)$ & (0.002) & $(0.004)$ & (0.003) \\
\hline \multirow[t]{2}{*}{ Number of children } & -0.008 & -0.002 & -0.005 & 0.092 \\
\hline & $(0.019)$ & $(0.014)$ & (0.032) & $(0.048)$ \\
\hline \multirow[t]{2}{*}{ Child under 3} & 0.035 & -0.060 & 0.098 & 0.093 \\
\hline & $(0.049)$ & $(0.051)$ & $(0.067)$ & $(0.076)$ \\
\hline \multirow[t]{2}{*}{ Any child } & -0.106 & 0.073 & 0.115 & -0.086 \\
\hline & $(0.061)$ & $(0.046)$ & $(0.086)$ & $(0.090)$ \\
\hline \multirow[t]{2}{*}{ Education } & -0.025 & -0.012 & -0.003 & -0.012 \\
\hline & $(0.010)$ & $(0.008)$ & $(0.015)$ & $(0.011)$ \\
\hline \multirow[t]{2}{*}{ GHQ } & -0.130 & -0.011 & -0.093 & 0.078 \\
\hline & $(0.085)$ & $(0.046)$ & $(0.134)$ & $(0.136)$ \\
\hline \multirow[t]{2}{*}{ Family values index } & 0.102 & 0.054 & 0.008 & 0.204 \\
\hline & $(0.100)$ & $(0.069)$ & $(0.109)$ & $(0.114)$ \\
\hline \multirow[t]{2}{*}{ Relationship duration } & -0.005 & 0.001 & -0.008 & 0.005 \\
\hline & $(0.003)$ & (0.002) & $(0.004)$ & $(0.004)$ \\
\hline \multirow[t]{2}{*}{ Year of separation } & -0.000 & -0.002 & -0.009 & -0.004 \\
\hline & $(0.005)$ & $(0.003)$ & $(0.006)$ & $(0.005)$ \\
\hline \multirow[t]{2}{*}{ Participation } & -0.019 & -0.034 & -0.127 & -0.052 \\
\hline & $(0.056)$ & $(0.021)$ & $(0.085)$ & (0.072) \\
\hline \multirow[t]{2}{*}{ Hours worked } & 0.001 & 0.000 & 0.000 & 0.002 \\
\hline & (0.002) & $(0.000)$ & $(0.001)$ & $(0.001)$ \\
\hline \multirow[t]{2}{*}{ Labor income (£000) } & 0.002 & 0.001 & 0.000 & -0.005 \\
\hline & $(0.003)$ & $(0.001)$ & $(0.003)$ & $(0.003)$ \\
\hline \multirow[t]{2}{*}{ Receives benefits } & 0.151 & -0.018 & -0.110 & 0.025 \\
\hline & $(0.057)$ & $(0.025)$ & $(0.076)$ & $(0.038)$ \\
\hline \multirow[t]{2}{*}{ Eq. household income (£000) } & -0.002 & -0.001 & -0.002 & 0.000 \\
\hline & (0.002) & $(0.001)$ & $(0.003)$ & (0.002) \\
\hline \multirow[t]{2}{*}{ Any asset income } & -0.023 & -0.007 & -0.131 & 0.047 \\
\hline & $(0.042)$ & $(0.027)$ & $(0.052)$ & (0.052) \\
\hline \multirow[t]{2}{*}{ Home owner } & -0.006 & 0.030 & -0.004 & -0.049 \\
\hline & $(0.040)$ & $(0.024)$ & $(0.064)$ & $(0.035)$ \\
\hline \multirow[t]{2}{*}{ Share of household income } & -0.036 & -0.083 & 0.086 & 0.073 \\
\hline & (0.123) & $(0.040)$ & $(0.154)$ & $(0.108)$ \\
\hline Observations & 456 & 427 & 385 & 342 \\
\hline
\end{tabular}

Robust standard errors in parentheses. Bold indicates significance at $5 \%$ level. Results should be compared to those in columns (2), (4) and (6) of table 4 . Other controls as in table 3. 
Table A3: Robustness: change in equivalized household income

\begin{tabular}{lccccccccc}
\hline $\begin{array}{l}\text { Scale } \\
\text { Year }\end{array}$ & \multicolumn{3}{c}{ OECD } & \multicolumn{3}{c}{ Square root } & \multicolumn{3}{c}{ Per capita } \\
\hline Baseline change & -0.514 & -0.294 & -0.230 & -0.594 & -0.357 & -0.285 & -0.426 & -0.218 & -0.146 \\
& & & & & & & \\
Cohabit & $\mathbf{0 . 2 8 4}$ & $\mathbf{0 . 2 3 1}$ & $\mathbf{0 . 1 8 7}$ & $\mathbf{0 . 3 0 6}$ & $\mathbf{0 . 2 3 8}$ & $\mathbf{0 . 1 8 4}$ & $\mathbf{0 . 2 5 7}$ & $\mathbf{0 . 2 0 7}$ & $\mathbf{0 . 1 7 9}$ \\
& $(0.082)$ & $(0.089)$ & $(0.084)$ & $(0.084)$ & $(0.091)$ & $(0.086)$ & $(0.080)$ & $(0.088)$ & $(0.085)$ \\
Cohabit*Infant & $\mathbf{- 0 . 3 1 1}$ & $\mathbf{- 0 . 3 0 0}$ & $\mathbf{- 0 . 3 3 7}$ & $\mathbf{- 0 . 3 5 3}$ & $\mathbf{- 0 . 3 2 2}$ & $\mathbf{- 0 . 3 5 6}$ & $\mathbf{- 0 . 2 6 7}$ & $\mathbf{- 0 . 2 5 5}$ & $\mathbf{- 0 . 3 2 1}$ \\
& $(0.115)$ & $(0.114)$ & $(0.138)$ & $(0.121)$ & $(0.120)$ & $(0.143)$ & $(0.114)$ & $(0.113)$ & $(0.137)$ \\
Cohabit*D Duration & -0.013 & -0.016 & -0.006 & -0.013 & -0.016 & -0.005 & -0.011 & -0.014 & -0.006 \\
& $(0.010)$ & $(0.010)$ & $(0.008)$ & $(0.010)$ & $(0.010)$ & $(0.008)$ & $(0.009)$ & $(0.009)$ & $(0.008)$ \\
Infant & 0.039 & 0.166 & 0.067 & 0.039 & 0.160 & 0.051 & 0.008 & 0.126 & 0.060 \\
& $(0.090)$ & $(0.089)$ & $(0.097)$ & $(0.093)$ & $(0.093)$ & $(0.101)$ & $(0.090)$ & $(0.089)$ & $(0.094)$ \\
Duration & $\mathbf{0 . 0 1 3}$ & $\mathbf{0 . 0 1 5}$ & $\mathbf{0 . 0 1 7}$ & $\mathbf{0 . 0 1 3}$ & $\mathbf{0 . 0 1 5}$ & $\mathbf{0 . 0 1 7}$ & $\mathbf{0 . 0 1 3}$ & $\mathbf{0 . 0 1 5}$ & $\mathbf{0 . 0 1 6}$ \\
& $(0.005)$ & $(0.006)$ & $(0.006)$ & $(0.005)$ & $(0.006)$ & $(0.006)$ & $(0.005)$ & $(0.005)$ & $(0.005)$ \\
\hline \hline
\end{tabular}

Robust standard errors in parentheses. Bold indicates significance at $5 \%$ level. Results should be compared to those in columns (2), (4) and (6) of table 4. Other controls as in table 3. 
Table A4: Change in women's log absolute household income on separation: by number of children

\begin{tabular}{|c|c|c|c|c|c|c|}
\hline & \multicolumn{2}{|c|}{ Year 0} & \multicolumn{2}{|c|}{ Year 1} & \multicolumn{2}{|c|}{ Year 2} \\
\hline & (1) & $(2)$ & $(3)$ & $(4)$ & $(5)$ & $(6)$ \\
\hline \multicolumn{7}{|l|}{ A: No children } \\
\hline Baseline change & -0.695 & & -0.513 & & -0.412 & \\
\hline \multirow[t]{2}{*}{ Cohabit } & 0.613 & 0.302 & 0.466 & 0.385 & 0.602 & 0.186 \\
\hline & $(0.106)$ & $(0.127)$ & $(0.095)$ & $(0.137)$ & $(0.101)$ & $(0.126)$ \\
\hline \multirow[t]{2}{*}{ Cohabit*Duration } & & -0.027 & & -0.032 & & -0.005 \\
\hline & & $(0.020)$ & & (0.022) & & $(0.013)$ \\
\hline \multirow[t]{2}{*}{ Duration } & & 0.011 & & 0.021 & & 0.016 \\
\hline & & $(0.009)$ & & $(0.008)$ & & $(0.008)$ \\
\hline Observations & 339 & 339 & 292 & 292 & 267 & 267 \\
\hline \multicolumn{7}{|l|}{ B: One child } \\
\hline Baseline change & -0.737 & & -0.383 & & -0.294 & \\
\hline \multirow[t]{2}{*}{ Cohabit } & 0.200 & 0.104 & 0.153 & -0.090 & 0.040 & -0.250 \\
\hline & $(0.124)$ & $(0.170)$ & $(0.109)$ & $(0.168)$ & $(0.130)$ & $(0.173)$ \\
\hline \multirow[t]{2}{*}{ Cohabit*Duration } & & 0.011 & & 0.013 & & $0.028+$ \\
\hline & & $(0.013)$ & & (0.012) & & $(0.016)$ \\
\hline \multirow[t]{2}{*}{ Duration } & & 0.002 & & -0.008 & & -0.009 \\
\hline & & $(0.009)$ & & $(0.010)$ & & $(0.013)$ \\
\hline Observations & 194 & 194 & 175 & 175 & 154 & 154 \\
\hline \multicolumn{7}{|c|}{ C: More than one child } \\
\hline Baseline change & -0.731 & & -0.376 & & -0.252 & \\
\hline \multirow[t]{2}{*}{ Cohabit } & 0.166 & 0.074 & 0.041 & -0.142 & 0.164 & -0.041 \\
\hline & $(0.098)$ & $(0.176)$ & (0.092) & $(0.170)$ & (0.102) & (0.202) \\
\hline \multirow[t]{2}{*}{ Cohabit*Duration } & & -0.009 & & -0.008 & & 0.001 \\
\hline & & $(0.017)$ & & $(0.019)$ & & $(0.020)$ \\
\hline \multirow[t]{2}{*}{ Duration } & & -0.002 & & -0.009 & & 0.008 \\
\hline & & (0.012) & & $(0.013)$ & & $(0.016)$ \\
\hline Observations & 244 & 244 & 223 & 223 & 206 & 206 \\
\hline
\end{tabular}

Dependent variable: change in log absolute household income from last observation within relationship to indicated observation year post-relationship. Robust standard errors in parentheses. Bold indicates significance at $5 \%$ level. Controls in columns (2), (4) and (6) as in table 3. Observations classified by number of children in household before relationship breakdown occurred. 
Table A5: Change in men's log household income on separation

\begin{tabular}{|c|c|c|c|c|c|c|}
\hline & \multicolumn{2}{|c|}{ Year 0} & \multicolumn{2}{|c|}{ Year 1} & \multicolumn{2}{|c|}{ Year 2} \\
\hline & $(1)$ & $(2)$ & $(3)$ & $(4)$ & $(5)$ & $(6)$ \\
\hline \multicolumn{7}{|l|}{ Absolute income } \\
\hline Baseline change & -0.231 & & -0.159 & & -0.050 & \\
\hline \multirow[t]{2}{*}{ Cohabit } & 0.067 & 0.038 & 0.168 & 0.367 & 0.104 & 0.114 \\
\hline & $(0.074)$ & $(0.138)$ & $(0.066)$ & $(0.119)$ & $(0.084)$ & $(0.121)$ \\
\hline \multirow[t]{2}{*}{ Cohabit*Infant } & & -0.042 & & -0.314 & & -0.332 \\
\hline & & $(0.180)$ & & $(0.175)$ & & $(0.248)$ \\
\hline \multirow[t]{2}{*}{ Cohabit*Duration } & & -0.016 & & -0.025 & & 0.020 \\
\hline & & $(0.019)$ & & $(0.018)$ & & $(0.015)$ \\
\hline \multirow[t]{2}{*}{ Infant } & & 0.051 & & 0.030 & & 0.180 \\
\hline & & $(0.126)$ & & (0.123) & & $(0.116)$ \\
\hline \multirow[t]{2}{*}{ Duration } & & 0.004 & & 0.014 & & 0.009 \\
\hline & & $(0.006)$ & & $(0.006)$ & & $(0.006)$ \\
\hline \multicolumn{7}{|c|}{ Equivalized income } \\
\hline Baseline change & 0.215 & & 0.192 & & 0.229 & \\
\hline \multirow[t]{2}{*}{ Cohabit } & -0.222 & -0.079 & -0.101 & 0.270 & -0.110 & 0.141 \\
\hline & $(0.068)$ & $(0.131)$ & $(0.064)$ & $(0.115)$ & $(0.081)$ & (0.121) \\
\hline \multirow[t]{2}{*}{ Cohabit*Infant } & & -0.125 & & -0.319 & & -0.303 \\
\hline & & $(0.164)$ & & $(0.160)$ & & (0.227) \\
\hline \multirow[t]{2}{*}{ Cohabit*Duration } & & -0.003 & & -0.020 & & 0.011 \\
\hline & & $(0.017)$ & & $(0.014)$ & & (0.012) \\
\hline \multirow[t]{2}{*}{ Infant } & & -0.010 & & -0.039 & & -0.030 \\
\hline & & (0.123) & & (0.129) & & $(0.111)$ \\
\hline \multirow[t]{2}{*}{ Duration } & & 0.006 & & 0.018 & & 0.016 \\
\hline & & $(0.006)$ & & $(0.006)$ & & $(0.006)$ \\
\hline Observations & 544 & 544 & 483 & 483 & 427 & 427 \\
\hline
\end{tabular}

Dependent variable: change in log (equivalized) household income from last observation within relationship to indicated observation year post-relationship. Control variables are characteristics before relationship breakdown. Robust standard errors in parentheses. Bold indicates significance at $5 \%$ level. Controls in columns (2), (4) and (6) as in table 3. 
Table A6: Relationship between cohabitation and contact with parents: women

\begin{tabular}{|c|c|c|c|c|c|c|c|c|}
\hline & \multicolumn{2}{|c|}{ Parent alive } & \multicolumn{2}{|c|}{ Parent $<1$ hour } & \multicolumn{2}{|c|}{ See weekly } & \multicolumn{2}{|c|}{ Receive help } \\
\hline Baseline proportion & 0.735 & & 0.752 & & 0.626 & & 0.418 & \\
\hline \multirow[t]{2}{*}{ Cohabit } & 0.186 & -0.016 & 0.015 & -0.028 & 0.015 & 0.018 & 0.107 & 0.010 \\
\hline & $(0.014)$ & $(0.015)$ & $(0.020)$ & (0.022) & (0.023) & $(0.026)$ & $(0.024)$ & $(0.026)$ \\
\hline \multirow[t]{2}{*}{ Age } & & -0.018 & & -0.006 & & -0.006 & & -0.015 \\
\hline & & $(0.001)$ & & $(0.001)$ & & $(0.001)$ & & $(0.001)$ \\
\hline \multirow[t]{2}{*}{ Education } & & 0.009 & & -0.064 & & -0.059 & & -0.007 \\
\hline & & $(0.004)$ & & $(0.006)$ & & $(0.007)$ & & $(0.007)$ \\
\hline \multirow[t]{2}{*}{ No. of children } & & 0.054 & & -0.009 & & -0.011 & & 0.065 \\
\hline & & $(0.006)$ & & $(0.009)$ & & $(0.011)$ & & $(0.011)$ \\
\hline \multirow[t]{2}{*}{ Infant } & & -0.047 & & -0.013 & & 0.065 & & 0.045 \\
\hline & & $(0.013)$ & & $(0.027)$ & & $(0.030)$ & & (0.032) \\
\hline \multirow[t]{2}{*}{ Hours worked } & & 0.001 & & 0.001 & & -0.000 & & 0.000 \\
\hline & & $(0.001)$ & & $(0.001)$ & & $(0.001)$ & & $(0.001)$ \\
\hline \multirow[t]{2}{*}{ Home owner } & & 0.022 & & 0.064 & & 0.101 & & 0.057 \\
\hline & & $(0.016)$ & & (0.023) & & $(0.026)$ & & $(0.026)$ \\
\hline \multirow[t]{2}{*}{ Participation } & & 0.044 & & 0.028 & & 0.006 & & 0.003 \\
\hline & & $(0.018)$ & & $(0.026)$ & & $(0.028)$ & & (0.022) \\
\hline \multirow[t]{2}{*}{ Eq. hh income } & & 0.002 & & -0.005 & & -0.004 & & -0.001 \\
\hline & & $(0.001)$ & & $(0.001)$ & & $(0.001)$ & & $(0.002)$ \\
\hline Observations & 2934 & 2934 & 2271 & 2271 & 2277 & 2277 & 2277 & 2277 \\
\hline
\end{tabular}

Estimates from wave 11 cross section for all women observed living as a couple who provide valid responses to questions about parents. Parent proximity, frequency of seeing parents and receiving help from parents are conditional on a parent being alive. Robust standard errors in parentheses. Bold indicates significance at $5 \%$ level. 